International Journal of

Culture and Religious

Studies

(IJCRS)
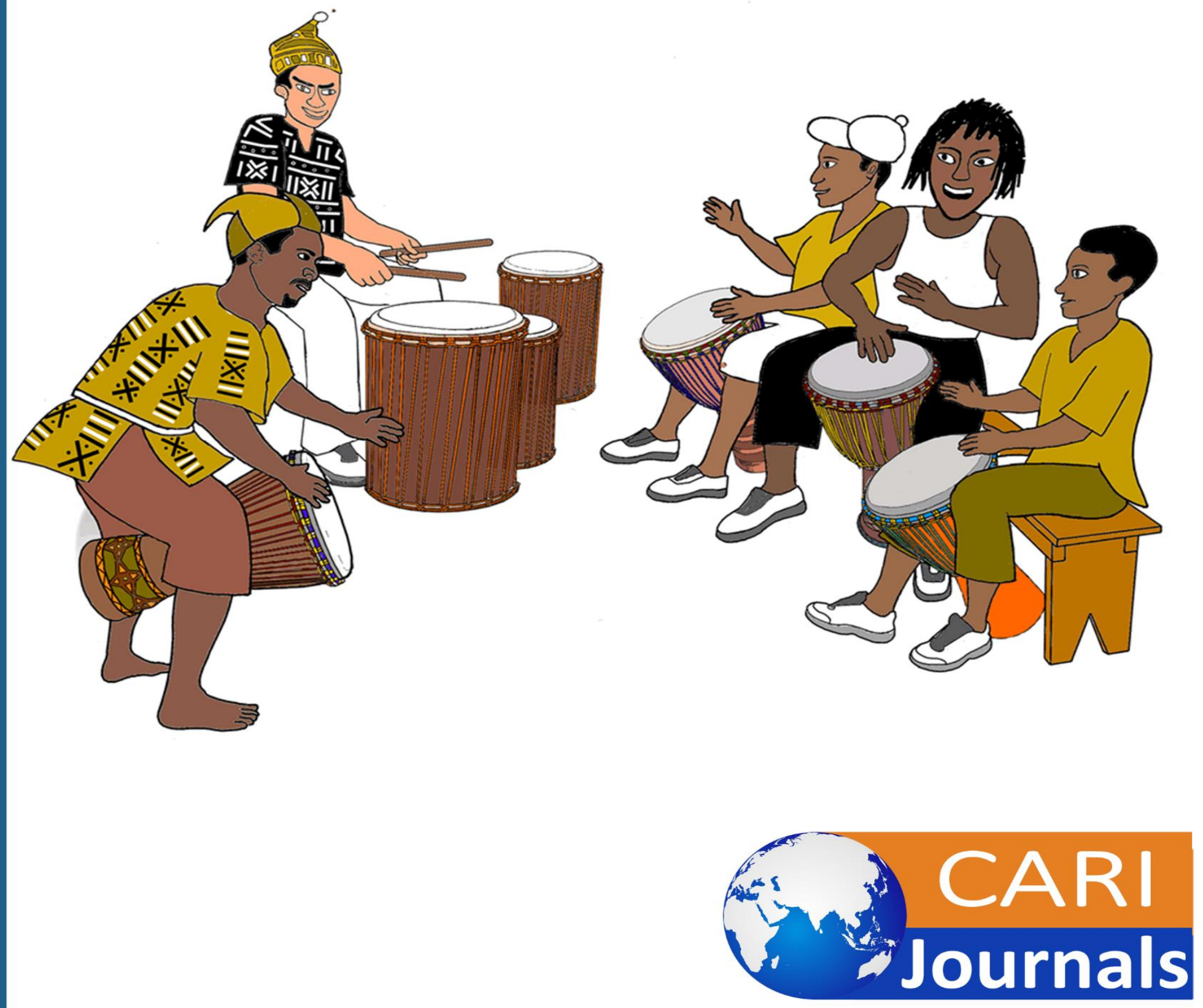
International Journal of Culture and Religious Studies

ISSN 2789-3898 (Online)

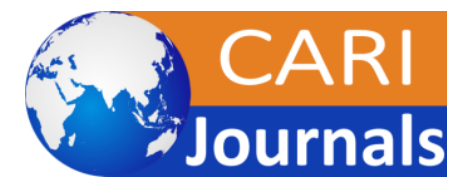

Vol. 2, Issue No. 3, pp 75 - 102, 2021

WWW.carijournals.org

\title{
"THE IMPACT OF PASTORAL MINISTRY BASED ON I SAMUEL 28:1-25 IN THE SPIRITUAL QUALITY OF EVANGELICAL KALIMANTAN CHURCH WHO FOLLOW THE TANTULAK AMBUN RUTAS MATEI IN KATINGAN CENTRAL KALIMANTAN"
}

\author{
Rina Teriasi \\ Institut Agama Kristen Kristen Negeri,Palangka Raya \\ *Email: rinateriasi74@gmail.com \\ Netto WS Rahan \\ Universitas Palangka Raya \\ *Email: netto.rahan@yahoo.com \\ Muner Daliman \\ Sekolah Tinggi Teologi Kadesi, Yogyakarta \\ *Email: munerdaliman16@gmail.com \\ Christianus Uda \\ Sekolah Tinggi Teologi Kadesi, Yogyakarta \\ *Email: crisuda287@gmail.com
}

The Ngaju Dayak people still respect and appreciate their families despite their different religions. This attitude is based on the huma betang philosophy of the Ngaju Dayak tribe. That they are one big family, one descendant, one ancestor. Therefore it is difficult for the congregation to leave the traditional rituals for this reason, pastoral care is needed from the pastor of the Evangelical Kalimantan Church by building relationships to make it easier to provide a biblical understanding. It is indicated that pastoral care for the members of the congregation has not been maximally carried out by the pastor, resulting in the foundation of the congregation's faith being shallow in interpreting life in obedience to God's word. It can be seen from the indications that there are still members of the congregation violating the teachings of the Christian faith by practicing rituals related to the traditions and beliefs of their ancestors. Therefore, based on the description of the background of the problem, it can be formulated as follows: 1)How big is the significant level of influence in building relationships with others based on I Samuel 28:1-25 on the spiritual quality of the members of the Evangelical Kalimantan Church who attended the TantulakAmbunRutasMatei ceremony in Katingan district, Central Kalimantan? 2)How big is the significant level of influence in building a relationship with Godbased on I Samuel 28:1-25 on the spiritual quality of the members of the Evangelical Kalimantan Church who attended the TantulakAmbunRutasMatei ceremony in Katingan district, Central Kalimantan? 3) How muchbig significant level What is the effect of pastoral care based on I Samuel 28:1-25 on the spiritual quality of the members of the Evangelical Kalimantan Church who attend the TantulakAmbunRutasMatei ceremony in Katingan district, Central Kalimantan? 
International Journal of Culture and Religious Studies

ISSN 2789-3898 (Online)

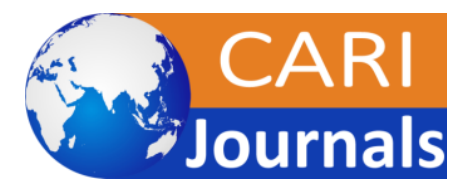

Vol. 2, Issue No. 3, pp 75 - 102, 2021

WWW.carijournals.org

Key words: Impact, Pastoral Ministry,TantulakAmbun Ceremony RutasMatei, I Samuel 28:125, Central Kalimantan

\section{INTRODUCTION}

Kalimantan Evangelical Church is one of the largest churches on the island of Borneo. The Evangelical Kalimantan Church, which is briefly referred to and known by spreading over five provincial areas on the island of Kalimantan, namely Central Kalimantan, South Kalimantan, West Kalimantan, East Kalimantan, and North Kalimantan. So, the members of the Evangelical Kalimantan Church are scattered throughout the island of Borneo. And the head office of the Kalimantan Evangelical Church Synod is located in the capital city of South Kalimantan, namely in Banjarmasin.

In church history, it is recorded that the Evangelical Kalimantan Church is a pioneer in the birth and growth of Christianity on the island of Borneo. The Evangelical Kalimantan Church is the fruit of the ministry of missionaries sent by a missionary agency from Germany, namely RMG (Rheinische Missions Gesselschft). In 1835 RMG (Rheinische Missions Gesselschft) sent its first missionary named Barnstein to preach the gospel to the island of Borneo to the Dayak people who still adhere to tribal religious beliefs as a legacy of the ancestors of the Dayak tribe called the Kaharingan. The Dayak tribe itself calls it religion Hyang'stattoo (ancestral religion) or TemponTelon religion (in the ancient Dayak language Sangen). After the entry of Christianity, the Kaharingan religion was called the Heiden religion (infidels), or Helo (the ancient religion). Since the Japanese occupation, this belief was given the name Kaharingan by DamangYohanesSalilah. And the name was accepted by the Japanese government, which was then accepted by all parties until now. ${ }^{1}$

Kaharingan recognized as one of the official religions in Indonesia that integrates with Hindu Dharma based on the Decree of the Minister of Religion of the Republic of Indonesia Number H/37/SK/1990 dated April 19, 1980. ${ }^{2}$ Thus the belief of the Ngaju Dayak tribe and their customs with all kinds of rituals can be maintained. And its role is felt both for the life of the Dayak tribe who are Kaharingan as well as Christians and Muslims. Kaharingan itself comes from the word herring, which in the ancient Dayak language (Sangen language) means "selfexistent" contained in the Balinese speech, namely "pantisnyalongkaharinganbelom, Tahutangohongkapatiningtahaseng". It means that the water droplets are alive by themselves, the flow of the river that carries the breath ${ }^{3}$

One of them in the event of death, usually the Ngaju Dayak tribe performs a series of activities and rituals, namely: a). Manatum (wailing) performed by the simati family. b). UsikLiua is a soccer game that aims to comfort grieving families. c). Burial. d). TantulakAmbunRutasMatei or Mapas Pali is a ceremony to take the spirits of the dead (Liua) to a temporary resting place at Lewu Bukit NalianLanting. There his spirit (Liua) will stay for a while until the time comes for his family to take him to Lewu Tatau in the Tiwah ceremony. The

\footnotetext{
${ }^{1}$ Hermogenes Ugang, Tracing the Paths of Nobility, (Jakarta: BPK Gunung Mulia), page 10

${ }^{2}$ Y. Nathan Ilon, Illustration and Embodiment of the Coat of Arms of Batang Garing and Dandang Tingang: A The Conception of Humanizing Humanity in the Philosophy of the Ngaju Dayak Tribe, Central Kalimantan,(Palangka Raya: PBP DATI I Central Kalimantan, 1991), 7

${ }^{3}$ Hermogenes Ugang,Op - Cit, 11 - 12
} 
TantulakAmbunRutasMatei ritual itself is carried out on the third day after the funeral. As long as the TantulakAmbunRutasMatei ritual has not been carried out, ${ }^{4}$ The TantulakAmbunRutasMatei ritual also aims to purify the spirit of the deceased from all sins and mistakes during his life and to purify family members and their household from all bad or unlucky influences due to death.

Associated with the death rituals as mentioned above, in the belief structure of the Ngaju Dayak tribe it is believed that humans can communicate directly with the spirits of the dead with the aim of inviting the spirits of the deceased to attend a ritual to inform about certain events or events. to advise living humans. The ritual ceremony is facilitated by a priest or intermediary called the tawur and basir (basir is the leader of the ceremony). The tawur is an influential man, for example the village head. The tawur has knowledge of the myths of the Ngaju Dayak tribe and has the ability to communicate with spirits including having the ability to communicate with the spirits of people who have died. Tawur can communicate with spirits to ask for directions if someone is going to travel far, spirits can give directions, for example telling a place in the forest where there is a farm to work on. The Spirit can also give clues to people who are sick, whether their illness can be cured or not. When the tawur invites the presence of the spirit, the sign of the presence of the spirit by being present is the sound of knocking. ${ }^{5}$

The tradition is the same as the traditions and beliefs that were lived in primitive Jewish society about the belief in the world of the dead (Sheol). In the Jewish tradition, the realm of the dead is a continuation of existence in the form of a shadow ${ }^{6}$. Those who are in the realm of the dead belong to the 'elohim' i.e. non-natural or supernatural persons (1 Samuel 28:15). The world of the dead or Sheol for the Jewish community is a place of waiting for the dead who are unable to do anything. Those who have died and the tradition of burial of corpses in the Jewish tradition has a meaning not only to honor the dead but also to ensure their tranquility in the underworld. ${ }^{7}$ namely Sheol and peace to him in fellowship with his fathers. Furthermore, Judging from the historical context and diachronic perspective, the practice of summoning spirits before the mid-eighth century BC may indeed not be a ban from the biblical text. Nor was it even forbidden by some of the prophets before Isaiah (cf. Isa 8:19; Isa 19:3, 29:4; Isa 57:6). However, necromancy began to be viewed negatively or badly after the 750s BC mainly because of the influence of the meaning of the text of 1 Samuel 28 which tells the story of a woman who summons a spirit in Endor. ${ }^{8}$

In 1 Samuel 28, it is known that this practice of consulting the spirits of the dead took the place and role of God and his prophets. The reason is that these sorcerers or seers cannot reconcile anyone with God. However, not all of Israel punishes all who come into contact with

\footnotetext{
${ }^{4}$ Ibid, $89-93$.

${ }^{5}$ Hans Scharer, Op-Cit, pp. 124-125

${ }^{6}$ Geoffrey. W. Bromiley. The International Standard Bible Encyclopedia, Volume Four: QZ. 1988. Michigan: Grand Rapids, 472.

${ }^{7}$ Theodore J. Lewis. Cults of the Dead in Ancient Israel and Ugarit in Journal of Near Eastern Studies, Vol. 53, No. 2 (Apr., 1994), 153.

${ }^{8}$ Mark S. Smith and Elizabeth M. Bloch-Smith. Death and Afterlife in Ugarit and Israel, in Journal of the American Oriental Society, Vol. 108, No. 2 (Apr. - Jun., 1988), 281.
} 
the $\operatorname{dead}^{9}$ The prohibition of the practice of summoning spirits was made clearer in Israel when the spirits of the dead were aligned with the role of God, as King Saul did. ${ }^{10}$. So what then makes Israel's attitude towards the underworld somewhat negative, especially because it creates a cult regarding the dead or asks the secrets of the unseen world through them for human life on earth. There is a certain concern that it turns out that the spirits of these dead people can give a true clue to humans. This is also the concern of the researcher that there are members of the Evangelical Kalimantan Church who misinterpret the TantulakAmbunRutasMatei ceremony by having certain tendencies, for example asking the spirits as Saul did in 1 Samuel 28. For this reason, pastoral care is needed so that every congregation has mindset and quality of faith in accordance with the Bible without leaving the culture of the ancestors.

Pastoral services are carried out by the servants of God of the Evangelical Kalimantan Church as a preventive measure for the church so that members of the congregation are not shallowed by teachings that can mislead as stated in the Association of Kalimantan Church Regulations E Number 44 of 2016 concerning the Implementation of pastoral care within the Evangelical Kalimantan Church (GKE). When there is a deviation in the behavior of the members of the congregation, the Church performs pastoral or pastoral services to foster and guide the congregation so that the congregation does not go astray and disappear from the fellowship of believers considering that the Dayak tribe consists of several tribal children including the Dayak tribe in Central Kalimantan, which is called the Dayak tribe. Dayak Ngaju. The Ngaju Dayak tribe is a society that really respects and upholds customs (Ngaju Dayak language: hadat) ${ }^{11}$ inherited by their ancestors. The inherited customs involve everything in the life of the Ngaju Dayak tribe, such as how to dress, how to behave and behave, how to respect ancestors, how to perform belief rituals, and other similar things. ${ }^{12}$

Through pastoral ministry or pastoral care, it is the soul of the church's ministry as a whole, because in it it does not only pay attention to the relationship between human beings but also the relationship between humans and God, and places God in human relations with each other. This makes pastoral ministry a valuable tool through which the Church can serve human needs holistically. ${ }^{13}$ In mission services, coaching, diakonia and various actions and actions taken by the church for the congregation must touch and contain pastoral or pastoral elements. Because in various forms of action the church must be oriented to love. Love is a major element in the ministry of the church. Any form of service is an act of saving love; helpful acts and acts of love; actions and acts of love that reach out to all; actions and acts of love that care about the struggles and sufferings of others. Love is the moving spirit in service. In accordance with the context of 1 Samuel 28:1-25 his pastoral ministry lies in the ethical actions taken in making the right decisions in times of urgency as did Achish and David.

Because in 1 Samuel 28 it is seen that Saul was so desperate because God did not answer his prayer that he ended up acting like a man who was very sick; looking for a cure, but he

\footnotetext{
${ }^{9}$ Mark S. Smith and Elizabeth M. Bloch-Smith. Death and Afterlife in Ugarit and Israel, 281

${ }^{10}$ Henry Preserved Smith. A Critical and Exegetical Commentary on The Books of Samuel. 1977. Edinburgh: T\&T Clark, 239.

${ }^{11}$ In the belief system of the Ngaju Dayak people, hadat/adat is the rule of life that was revealed directly by RanyingHatalaLangit.

12 Hermogenes Ugang, Tracing the Paths of Nobility, (Jakarta: BPK GunungMulia, 1983), p. 50.

${ }^{13}$ YakobTomatala, Mission Theology., YT Leadership Foundation, Jakarta, 2003, page 61
} 
couldn't find it $^{14}$. When the various methods of treatment did not give hope, then Saul began to leave what had been his belief. When a belief that gave no hope, Saul left (verse 7). He began to violate Samuel's trust, to violate the prohibitions of Deuteronomy, to violate his obedience as king $^{15}$. In the end, His decision to seek help through an intermediary or a seer was a fatigue, despair and failure of Saul's faith and life. Similar to the situation faced by the members of the Evangelical Kalimantan Church, due to strong kinship ties and solidarity in the life of the Ngaju Dayak tribe, when facing the event of death, family members and local residents who are Christians and Muslims collectively help clean the house and help prepare the need for the implementation of the ritual as well as being present at the time of its implementation. As is the case in the implementation of the TantulakAmbunRutasMatei ritual. Family members and residents around the funeral home were also present at the time of its implementation.

Because it is undeniable that this pastoral or pastoral task is connected with the task of a pastor carried out by the pastor or servant of God of the Evangelical Kalimantan Church. The task of a pastor is to find and visit members of the congregation one by one, to spread the word of God in each individual's personal life situation to better understand his faith as a believer, to be obedient and obedient to God's word and to do it in daily life. Through pastoral or pastoral care, coaching is done to shape one's character to become a good disciple of Christ. ${ }^{16}$ or in other words, to keep the spiritual quality of the GKE congregation well maintained, especially for those who attend the ceremony TantulakAmbunRutasMateiBecause in addition to involvement in the ritual death ceremony of TantulakAmbunRutasMatei which was carried out by family members. Another fact that is still visible in the practice of religious life that does not obey God's word among the members of the Evangelical Kalimantan Church is that there are still members of the Kalimantan Evangelical Church in Katingan district who practice traditional ceremonies and beliefs of their ancestors. Among other things, doing self-medicating, still practicing mapaslewu in order to ask for protection so that the village or village is kept away from calamity, performing rituals before planting rice, believing in pali, believing in good days and unlucky days. This is where the challenge for the church, especially the challenge for the pastor to teach, guide, and save God's people so that the congregation understands the meaning of being born again as God's people who have received the gift of salvation from God through the sacrament of Holy Baptism and the Sacrament of Holy Communion. In pastoral development for the congregation, building relationships is very important. Building relationships is an entry point in pastoral care. Because in the relationship there is an encounter, communication and interaction between human beings when doing pastoral care. Building relationships in pastoral based on the point of view of the Christian faith is divided into two parts. The first is building relationships with others and the second is building relationships with God. As a person who served, Jesus was successful in preaching the word. Jesus' success in his ministry has always used relationships to reach out to any particular individual or community. Relationships are part of the

\footnotetext{
${ }^{14}$ Walter Brueggemann. First and Second Samuel Interpretation: A Bible Commentary for Teaching and Preaching. 1990. USA: John Knox Press, 192.

${ }^{15}$ Walter Brueggemann. First and Second Samuel Interpretation: A Bible Commentary for Teaching and Preaching, 193.

${ }^{16}$ JD Engel, Pastoral and Basic Needs Counseling, (Jakarta:BPKGunungMulia, 2016), page 5
} 
International Journal of Culture and Religious Studies

ISSN 2789-3898 (Online)

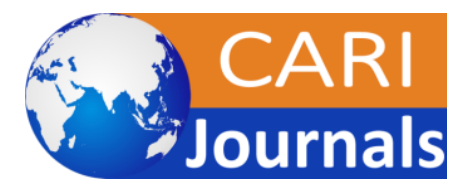

Vol. 2, Issue No. 3, pp 75 - 102, 2021

WWW.carijournals.org

key to Jesus' success in his pastoral ministry for humans so that God's word is able to change human lives to receive the gift of salvation from God, restoration and renewal in human life (John 2:1-11;3:1-17; 4:4) 4-27; Luke 20:45-47). Thus, in the context of the book of I Samuel 28:1-25, it implies building relationships with others. There are encounters, communication and interactions to guide, build, direct, guide, strengthen each other when in difficulties and struggles. That is a form of real concern or empathy in the pastoral relationship between Achish and David, between Saul and his servants (I Samuel 28:1; 2; 7). Relationships as part of the key to Jesus' success in his pastoral ministry for humans so that God's word is able to change human life to receive the gift of salvation from God, restoration and renewal in human life (John 2:1 $11 ; 3: 1-17 ; 4: 5)$ 4-27; Luke 20:45-47). Thus, in the context of the book of I Samuel 28:1-25, it implies building relationships with others. There are encounters, communication and interactions to guide, build, direct, guide, strengthen each other when in difficulties and struggles. That is a form of real concern or empathy in the pastoral relationship between Achish and David, between Saul and his servants (I Samuel 28:1; 2; 7). Relationships as part of the key to Jesus' success in his pastoral ministry for humans so that God's word is able to change human life to receive the gift of salvation from God, restoration and renewal in human life (John 2:1-11;3:1-17; 4:5) 4-27; Luke 20:45-47). Thus, in the context of the book of I Samuel 28:1-25, it implies building relationships with others. There are encounters, communication and interactions to guide, build, direct, guide, strengthen each other when in difficulties and struggles. That is a form of real concern or empathy in the pastoral relationship between Achish and David, between Saul and his servants (I Samuel 28:1; 2; 7). 4 - 27; Luke 20:45-47). Thus, in the context of the book of I Samuel 28:1-25, it implies building relationships with others. There are encounters, communication and interactions to guide, build, direct, guide, strengthen each other when in difficulties and struggles. That is a form of real concern or empathy in the pastoral relationship between Achish and David, between Saul and his servants (I Samuel 28:1; 2; 7). 4 - 27; Luke 20:45-47). Thus, in the context of the book of I Samuel 28:1-25, it implies building relationships with others. There are encounters, communication and interactions to guide, build, direct, guide, strengthen each other when in difficulties and struggles. That is a form of real concern or empathy in the pastoral relationship between Achish and David, between Saul and his servants (I Samuel 28:1;2;7).

Second, build a relationship with God. Building a relationship with God is central to the life of every believer. When every believer allows God to guide his life step by step, then the individual believer will begin to know every spiritual phase that must be passed and every spiritual target that must be achieved. So that the life of every believer will always be at the center of God's will. When every believer is at the center of God's will, will always enjoy God's protection and care, God's grace is always manifest in the lives of believers. From time to time God always sustains the lives of believers. A good relationship with God makes life reflect the quality of the spiritual life of believers.

Besides that, the most important thing is that it is hoped that through this research it can be seen how much pastoral care has been carried out by the Evangelical Kalimantan Church and its impact on the spiritual quality of the congregation who attended the TantulakAmbunRutasMatei ceremony. 


\section{RESEARCH OF METHOD}

According to Mohammad Nazir, research is a method or method of study that is carried out by someone carefully to understand something by going through an investigation or through an effort to find evidence that arises in connection with the problem so that the right solution to the problem is obtained..$^{17}$ In other words, in this study, the researcher will distribute to the respondents a number of statements in a questionnaire to get the answers needed for the completion of the writing that is examined by hypothesis testing. Populasi merupakan wilayah generalisasi yang terdiri atas obyek/subyek yang memiliki karakteristik tertentu dan kemudian ditetapkan oleh peneliti untuk dipelajari dan kemudian ditarik kesimpulannya.Populasi dalam penelitian ini adalah Warga Jemaat GKE Yang Mengikuti Upacara Tantulak Ambun Rutas Matei Di Kabupaten Katingan Kalimantan Tengah. Dari data yang diperoleh dari 4 gembala resortyaitu Majelis Resort GKE Kasongan, Majelis Resort GKE Pendahara, Majelis Resort GKE Buntut Bali, Majelis Resort GKE Tumbang Lahangjumlah warga Jemaat GKE Yang mengikuti Upacara Tantulak Ambun Rutas Matei adalah sejumlah 450 orang. Inilah yang menjadi populasi dalam penelitian ini.

\section{DISCUSSION AND RESULTS}

\section{Asking the spirits for guidance}

1 Samuel 28:15. After that Samuel spoke to Saul: "Why are you bothering me by calling me to appear?" Saul said, "I am in a very difficult situation: the Philistines are fighting against me, and God has turned away from me. He does not answer me anymore, neither by prophet nor by dream. Therefore I call you, that you may tell me what is happening. I have to do."

What is an abomination to God is to ask the spirits for guidance. Saul's confidence in the decisions and actions he did was right. Saul desperately needed a clue as to what would actually happen to him and the Israelites when they fought against the Philistines. Saul wanted to know immediately what the female seer who he met was predicting. Therefore, Saul immediately asked the summoning woman to summon the spirit of Samuel, which he believed would give Saul what he wanted. When the summoner said that an old man had appeared covered in robes, then he knelt down with his face to the ground and bowed down to worship the spirit that had appeared. Saul had committed an act that was displeasing and violated his own principle of summoning a spirit and worshiping it. ${ }^{18}$ Saul had violated God's law as the anointed king. God's people are not allowed to worship spirits as stipulated in Exodus 20:5 "Do not bow down to worship him or worship him, for I, the LORD your God, am a jealous God, repaying the iniquity of the father to his children, to the third and fourth generation of the family. those who hate me"

It is clear that from the text of 1 Samuel 28, it can be understood that this practice of consulting with the spirits of the dead took the place and role of YHWH and his prophets. The reason is that these sorcerers or seers cannot reconcile anyone with God. However, not all of 
Israel punishes all who come into contact with the dead ${ }^{19}$ because they also still hold the concept that the dead are a continuation of the existence of living in the world.

The prohibition of the practice of summoning spirits was made clearer in Israel when the spirits of the dead were aligned with the role of God, as King Saul did. ${ }^{20}$. So what then makes Israel's attitude towards the underworld a bit negative, especially because it creates a cult regarding the dead or asks the secrets of the unseen world through them for human life on earth. There is a certain concern that it turns out that the spirits of the dead can provide a true clue to humans. Whereas for the Israelites themselves, there was no place that could replace YHWH's place as the God of life.

One of Satan's lies was to disguise himself as a spirit prophet of God and tell lies to Saul. In the Bible, there is 1 verse that shows Satan's lies by disguised as a spirit that resembles a prophet of God. That spirit is the spirit of Samuel. In 1 Sam 28:14 it is said that there is a divine coming out of the earth. What's odd here is that it "came out of the earth". If we look at the Bible, the appearance of God and the holy angels never came from the earth. He and His angels always appear from the sky when they come to earth. How to prove that it's a demon spirit in disguise? First, at that time Saul was worried because he would face the Philistines while Samuel was dead and his body was buried in his own city, namely Rama. When Saul was anxious, he didn't come asking for God's help but he went to a seer woman/a shaman. This is contrary to God's guidance. God never told His prophet to come to a witch doctor and look for answers there. He himself will even eliminate the sorcerer from his presence.

Second, the appearance of God and His angels is always from above and not from below (John 1:51). Even God sent a fiery chariot to the prophet Elijah from above and not from below. So who's under who? Isa 14:15 says that God threw the rebellious angel into the realm of the dead which is the deepest place in the grave

Third, the Spirit of Samuel has died and is no longer alive. Everyone who dies, their mind will be cut off (Psalm 146:4). The spirit of His child will be saved by Him to be resurrected on the Day of Judgment on earth. (1 Cor 15:13). 1 Sam 28:16 says that the Spirit of Samuel told Saul that the Lord had withdrawn from Saul. The spirit lied to Saul because it was as if he was telling him that God did not take care of Saul. Whereas Saul was at fault because he did not come to God but to a woman who called a spirit.

Summoning the spirits of the dead is called necromancy. The term is derived from the Greek words nekros (the dead) and manteia (the act of miraculously knowing the future). So necromancy is the summoning of the spirits of the dead with the aim of revealing the future miraculously influencing events. The practice of necromancy in the Bible is not mentioned much, much less practiced. Allah clearly and strictly forbids this action. This prohibition is something strange when viewed from the perspective of the ancient nations at that time.

This view is quite popular among lay Christians, although only a few hold this view. Those who hold this view have given several arguments which they consider quite strong. First, the practice of necromancy was strictly forbidden by God, so it was impossible for God to work by confirming Samuel through seances. Second, the Bible teaches that there is no relationship between the dead and the living (Luke 16:27-31; Job 7:9; cf. Isa 26:14a). Third, God did not

19 Mark S. Smith and Elizabeth M. Bloch-Smith. Death and Afterlife in Ugarit and Israel, 281

20 Henry Preserved Smith. A Critical and Exegetical Commentary on The Books of Samuel. 1977. Edinburgh: T\&T Clark, 239. 
want to reveal anything to Saul anymore (1 Sam. 28:6). Fourth, this spirit appears in the earth (1 Sam. 28:13). Fifth, what was said by "Samuel's spirit" did not actually happen. Saul and his sons did die (1 Sam. 19; 31:2, 6-7).

Regarding the case of Samuel's summoning of the spirit in 1 Samuel 28, there is a sharp debate among biblical scholars, especially as to who was called out. According to Josh McDowell and Don Stewart, a number of evangelical scholars believe that it was Samuel who was called out. ${ }^{21}$ While others believe it is a demonic spirit in disguise and the latter believe it is a trick of a female shaman to deceive people. Therefore, in the following, the author will describe the pros and cons of Samuel's spirit and the author's own position in this debate. Samudera confirms that the spirit that appears in the case of summoning Samuel's spirit by the female shaman in Endor is really Samuel's spirit. Therefore, according to him, the interpretation that said that the female shaman in Endor was summoned was not the spirit of Samuel but the spirit of Satan, it is a wrong interpretation. Concluding his conviction, he stated, "It is clear that the dead can be called out of Hades by the living, as is evident in 1 Samuel 28:7-9."22

This belief is based on three arguments that he put forward as follows: first, the prohibition against contacting the spirits of the dead, he considered, proved that the relationship between the dead and the living could be carried out; ${ }^{23}$ second, what is prohibited is to ask for instructions on the spirits of the dead, not give instructions or evangelize the spirits of the dead; ${ }^{24}$ third, believers also have the same power as the Lord Jesus has over the underworld. ${ }^{25}$

The Bible's prohibition against the practice of spiritism makes no exceptions related to motivation, either for the purpose of seeking guidance or for instructing the soul (Leviticus 19:26b, 31). Likewise, the extermination of the summoners regardless of whether they gave or received instructions from the spirits of the dead (Ex 22:18; 1 Sam 28:3; 2 Kings 23:24). Then, the third argument, that believers or God's servants have the same power as Jesus' power over the world of the dead, also has no true basis, but instead reflects the basic nature of humans who want to be like God. (Gen. 3:5; 11:4).

The Bible makes a clear statement regarding the spirits of those who have experienced death: "If a man dies, can he live again? (Job 14:14). Job's question explains that death is a reality that all humans must face without exception. Death gives awareness to humans that human life is limited. Death can be experienced by anyone, big or small, young and old, unexpectedly and can occur due to hunger, disease, war and natural disasters. Death is the radical end of human existence. ${ }^{26}$ The term used in the Old Testament for death is mawet'mut (Hebrew) and the New Testament uses the word thanatos, nekros (Greek). ${ }^{27}$ Old Testament anthropology explains that man is not from God but was created by God (Genesis 1:27) or formed by God from the dust of the ground and was given life after God breathed into his

\footnotetext{
${ }^{21}$ Handbook of Today's Religions: Understanding the Occult (San Bernardino: Here's Life: 1982), p.164

${ }^{22}$ Ocean, World of the Dead, (Bandung: Revival, 1996). p, 48

${ }^{23}$ Andereas Samudera, Barang Tumpas, (Bandung:: Revival, 1998), p. 21

${ }^{24}$ Ibid, Ocean, p. 25

${ }^{25}$ Op.cit, Samudera, p.8

${ }^{26}$ Abineno. JL Ch. Humans and Others in the World, (Jakarta; Gunung Mulia), 1990, p. 24

${ }^{27}$ David N Freedman, (Ed), Eerdmans Dictionary of The Bible, Michigan:Word Eerdmarts Pblingshing Company, 2000, sv "mut and thanatos"
} 
International Journal of Culture and Religious Studies

ISSN 2789-3898 (Online)

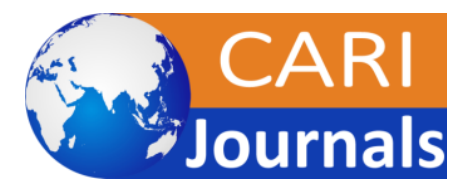

Vol. 2, Issue No. 3, pp 75 - 102, 2021

WWW.carijournals.org

nostrils the breath of life (Genesis 2:7). If humans are called creation then in humans there is an element of impermanence (mortality). In Genesis 2:36-17 there is a prohibition against eating the fruit of the knowledge of good and evil with the result of "death", mut. God's commandment was violated by man so that man died in the sense of being separated from God; not dead in a physical sense. The attitude of obedience to God was also expressed by the Lord Jesus when tempted by the devil in the desert (Marius 4:4). The Apostle Paul also spoke of humans who die (necros) in trespasses and sins (Ephesians 2:1, Romans 7:9). Stress word necros. is "dead" because it is condemned. In addition, in Romans 6:23, the Apostle Paul said that the wages of sin is death (thanatos) and which entered through Adam's sin (Romans 5:12).

As a result of sin, humans are cut off from their relationship with God. ${ }^{28}$ In Genesis 2:7 it says that God formed man from the dust of the ground. Allah puts the breath (neshamah) into physical form, and in that way man becomes a living being (nefeshchayyah). The entry of God's breath into humans does not mean that humans receive a divine soul or spirit. The idea of a divine spirit or soul is not found in the Old Testament; it only says that the spirit (ruach) or breath returns to Allah. (Ecclesiastes 12:7). The concept of ruach has the same meaning as pneuma in the New Testament. The conception of nefesh (soul) is the force that animates the body and cannot be imagined if it is outside the body. The Old Testament does not recognize trichotomy, the division of man into soul, spirit and body, or dichotomy, the division of man into soul and body. Spirit is not something separate from the soul. Spirit and soul can never be separated just like soul and body. When a human dies, the body enters the process of turning into soil again (dust). Obviously, death makes human life stop, but human shadows still live, a shadow in Sheol. The notion of the immortality of the soul is not known in the Bible. Humans experience death not because of God, but because of their own will to be like God. This main sin that brings death in human life. This deep spiritual view stems from the conflict between the Yahwist tradition and the ancient Eastern conception of the world. Humans are called the image of God (image of Gad), because humans have a special relationship with God in which humans are believed to rule the universe (Genesis 2:8-25). . Here humans live in an "innocent state" so that they are not ashamed when both are naked. Humans consisting of body, spirit and soul are referred to as fully human: humans as a totality. This complete human that God created and at the same time was saved by God after falling into sin. The salvation that God gives is not salvation for his soul only, but salvation for his body as well. Man is a unity of body and soul. A unified whole that cannot be separated. When a man dies, he dies entirely as body and soul. That's what the Bible says and that will happen to every human being. God is with man in his life and God is also with man when man dies and after man dies. It is clear that man dies as man in his totality. He died as his spiritual and bodily self. So physical death is an appropriate symbol that explains more deeply that death is the result of sin and is inevitable. If sin resulted in the death of man, then Christ was sent by God to take away the sins of man so that in Christ man was reconciled to God. In that way, God gives man a new possibility to live as his partner. then Christ was sent by God to take away the sins of mankind so that in Christ man was reconciled to God. ${ }^{29}$ In faith, death is seen as the result of disobedience to God. When humans die, the soul is

\footnotetext{
${ }^{28}$ Donald Guthrie, New Testament Theology 1: God, Man, Christ, (Jakarta: BPK Gunung Mulia, 1991), pp. 44-45

${ }^{29}$ Harun Hadiwijono. Christian Faith, (Jakarta: BPK Gunung Mulia. 2003), pp. 77-78
} 
separated from the body, the soul is not punished and does not "sleep" in the realm of death. After death, the soul enjoys heavenly peace while waiting for the resurrection of the flesh. The soul experiences a higher peace after being separated from the body and attains its perfection in the bliss of the resurrection of the flesh. The believer's soul after leaving the body continues to live and feel "provisional blessedness" in God even though it is not perfect. ${ }^{30}$ Perfection of peace occurs after the resurrection of the flesh later. The risen is the body and not the soul (1 Corinthians 15:54; John 2:29). The resurrected flesh will not perish and in union with the soul, is ready to face the judgment seat of Christ to receive the reward of eternal life. Even though man has fallen into sin, God loves him.

Sinners are saved by God only because of grace (sola gratia) in Jesus Christ so that humans should give thanks and glorify God (soli Deo Gloria) for the gift of salvation. RC Sproul, an American theologian and pastor, argues that the Bible often uses the Hebrew words for "breath" and "spirit" interchangeably. When a person dies his body becomes "dust" and the "spirit" ("breath of life") returns to God, who is the source. Man created in the image and likeness of God is a creature made of a material body and an immaterial soul. Both the body and the soul were created by God and are different aspects. This duality view illustrates that man is a single being with two different elements, united by God in creation. This human existence does not require the addition of other elements or substances (such as spirit) both philosophically and exegetically, to bridge the tension between the two elements that exist in humans. The body was created good and has no physical inheritance of evil. However, both body and soul have been morally defiled by sin. Man is a sinner in both body and soul. The human soul was created by God and did not originate from eternity. Although the soul is not made up of matter and cannot be destroyed by physical force it can be destroyed by Allah. The soul cannot exist without dependence on God, "For in Him we live, we move, and humans exist, as your poets have said: For we are also of God's seed" (Acts 17:28). ${ }^{31}$

At the time of death, even though the body dies, both the soul of the believer and the unbeliever live on. Believers await the fulfillment of their redemption, while unbelievers await God's judgment. Because God guards the soul from death, man has a constant awareness of his personal existence that transcends death. The whole human person fell into sin; both body and soul are objects of God's salvation given by His grace. Man created by God is a totality, a whole. Based on his interpretation of Genesis 2:7, nisymathayyim (life force) and nefesyhayah (living soul) were created by God, and not God's substance that came out of Himself. Nisymathayyimini is what is exhaled into the body taken from the ground so that the body becomes nefesyhayyah (living soul). Because Yahwist sources always describe God in His works anthropomorphically, the word yippah (exhale) is used, so that many people often understand nisymat as God's breath. As a result, there is a misunderstanding that the human soul is understood as "His soul" of God, which means that God's substance/divine element exists in man. The human body and soul are created and mortal. Therefore when he dies, he is in totality: his body and soul are subject to death. The dimensions of soul and spirit in humans experience death the same as their bodies. When the Bible speaks of the spirits of the dead (I Samuel 28:7; Ecclesiastes 12:7), it does not

\footnotetext{
${ }^{30}$ Yohanes Calvin, Institute: Teaching Christianity (Jakarta: BPK Gunung Mulia, 1985), p. 21

${ }^{31}$ RCSproul, Fundamental Truths of the Christian Faith, Trans. R.Tanudjaja, (Malang: Department of Literature SAAT, 1998), p. 88
} 
mean the soul/spirit dimension. on immortal humans, but what is emphasized is that humans in totality or as a whole "do not run out". Humans throughout, namely the refaim. (the image of man) remains in the anamnesis (memory) of Allah until he is resurrected. As long as the human is dead, during that time the dimensions of his soul and body do not have any power and do not exist as if the human was still breathing. Because the human soul and body have no power when he dies, the deceased is like a sleeping person (Luke 8:5253), Thus, the only one who is not subject to death is God, because He is eternal (I Timothy 6 :16) Man died completely and because of that man also rose completely. It is said to be fully awakened, because all human dimensions are "resurrected" in the power of God. God does not re-create for the resurrection of the dead, but he is also the one who is resurrected later. The future immortal life is not a new creation. It is the dead who will live the whole life in a perfect total personality, namely the body as well as the spiritual man. Thus, the dead human "I", "I" will also be resurrected in the future. ${ }^{32}$

Thus, the congregation must have the courage not to be crooked so that they ask the spirits who actually plunge people into suffering. Courage is one of the characteristics of spiritual qualities that must be possessed by the congregation.

\section{Worshiping spirits}

1 Samuel 28:14 Then he knelt down with his face to the ground and bowed down in worship.

What Saul worshiped at that time was not God but Saul worshiped the spirit of Samuel who came out and appeared before Saul. The word "worship" becomes an important thing because it is directly related to God Himself. DjohanHandoyo, one of the pioneers of praise and worship in Indonesia, explained: "The person of God is the Spirit. The dimension of worship as communication between us and God requires tongues as a liaison." 33

For the "mainstream and evangelical" the meaning of worship is not only in the liturgy of the church, but in all aspects. True worship is right living according to God's word. Even if worship is defined in the liturgy of worship, then worship is also not a practice of worship among pietists. This meaning was conveyed by John MacArthur:

"Worship is not a matter of being in the right place, at the right time. Worship is not an outward activity that requires the creation of a certain atmosphere. Worship takes place in the heart, in the spirit." 34 "The very nature of worship is to give worship to God from the deepest part of us, in praise, prayer, song, giving help, and living, always based on His revealed truth."

There are three main Hebrew words used in the Old Testament to describe worship; that is a word that is often translated in its English version as worship (worship). Biblical terminology states that worship is submission, service, reverence. ${ }^{35}$

The most common word for worship in the Old Testament is the Hebrew word hAwAh. The original form is hishtAhAwAh, which means bow down, to do obeisance, to pay homage, to

\footnotetext{
${ }^{32}$ Andreas Kabanga', Completely Dead Man: A Study of Christian Anthropology, Introduction: Prof.(Em)

Dr. Solarso Sopater, Yogyakarta: Media Pressindo, 2002, pp. 76-77

${ }^{33}$ Djohan E. Handoyo, Praise And Worship (Yogyakarta: ANDI Publisher, 2007), 50.

34 John MacArthur, Top Priorities in Worship (Bandung: Kalam Hidup, 2001), 151

35 Chris Jack, "Understanding Worship: Part 2" in Worshiping in Spirit and Truth, sixth edition (Yogyakarta: ANDI Publisher, 2010), 80.
} 
worship. There are 170 occurrences of the word hAwAh in the Old Testament, only less than half (approximately 75 times) are translated as worship in the NIV version. In more or less the same amount, the word bow down is used. "Prostrate" is clearly an important component in the meaning of the word. This body movement is a common thing in culture from time to time. Bowing is a way of honoring someone; a sign of respect. Bowing can also mean bowing down, especially when done in the presence of someone in authority. But one thing that is important in all of this is the purpose behind the posture shown. Of course, like other postures, this action can be performed only as a physical gesture, so it can be manipulated. However, actions and attitudes of the heart must go hand in hand. So, as a worship term, hAwAh conveys the idea of honoring Allah and expressing an attitude of submission to Him. ${ }^{36}$

The Bible chooses to use the word 'serve' rather than 'worship.' As used in various contexts that imply service to God, the word AbAd is also specifically used for religious services, including those related to worship (sacrifice ordinances etc.), for example in Numbers 3:7; 8:11. All the sacrificial ordinances were given by God to enable His people Israel to serve (worship) Him in the right way. ${ }^{37}$

The Greek word proskuneo is well summarized by H. Schonweiss and C. Brown in New InternAtionAlDictionAry of New TestAment Theology 2: For the Greeks, this verb is a technical term for worship of gods, which means to fall down, to subdue oneself, to worship with kneeling... apart from the outward attitude of subduing oneself in worship, the proskuneo can exhibit an inner attitude that corresponds to reverence and humility. ${ }^{38}$

The word proskuneo means "to kiss towards," "to kiss the hand," or "to bend down." This word is described as a dog kissing its master's hand. The word worship used to describe humble worship.11 The Greek word worship proskuneo means to worship, an attitude like a dog licking its master." ${ }^{39}$ A relationship that is close, respectful, gentle, obedient and full of harmonious affection. The notion of God as Spirit is not foreign to Judaism, but Jesus emphasized that His worshipers must also be in harmony with the One who is worshipped. The formalities of religious worship will touch nothing if done without the 'Spirit. ${ }^{10}$

Proskuneo is the most commonly used word for worship in the New Testament (see John 4:2024; Rev. 5:14), as is hAwAh in the Old Testament. The original idea behind the word was to pay homage, honor with a spirit of submission (and perhaps posture) to someone deemed worthy and superior. Like hAwAh, in essence this is an attitude of the heart that can be reflected through the attitude of the body. Both the meaning and usage of these two words, hAwAh and proskuneo, have very close parallels. ${ }^{41}$

Worship is a human response to the acceptance of a holy presence, a presence that is more important than normal and holy human activity. ${ }^{42}$ Marvin E. Tate defines worship in the Bible as moving continuously between personal and shared experiences. This brings man into an

\footnotetext{
${ }^{36}$ Ibid, p. 82

${ }^{37}$ Matt Redman, Worshiping in Spirit and Truth, sixth printing (Yogyakarta: ANDI Publishers, 2010 ), 83.

38 Ibid, p. 87

39 John MacArthur, JR, MAIN PRIORITIES IN WORSHIP (Bandung: Kalam Hidup, 2011), 26.

40 Ibid 35

${ }^{41}$ Marvin E. Tate, HolmAn Bible DictionAry for Window version 1.0g(Parsons Technology, 1994), sv "worship"

42Jey J. Kanaragaraj, "Worship, Sacrifice and Mission: Themes Interlocked in John," Indian Journal of Theology 40.1\&2 (1998):17.
} 
International Journal of Culture and Religious Studies

ISSN 2789-3898 (Online)

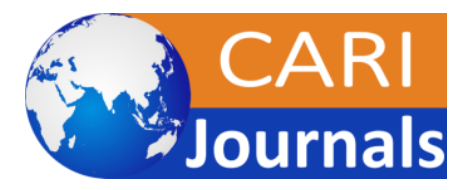

Vol. 2, Issue No. 3, pp 75 - 102, 2021

WWW.carijournals.org

intimate relationship with God. Allah created humans primarily for the purpose of worshiping Him. This call to worship demonstrates worship as a universal priority and the sole responsibility of every believer. This worship can only be expressed by giving your whole heart and life to Him. ${ }^{43}$

But in the context of this verse it shows that the form of worship of hawah / proskuneo prostration to the ground is not to God but is instead done to spirits who do not deserve to be worshiped. Therefore this shows that Saul's spiritual quality is questionable not focusing on worshiping God the same way the church should focus on worshiping God not on the things that God created. But to be a true devotee one must arise from a correct understanding of His word, His truth, His mercy, His nature. True worship reveals God as He has revealed Himself in His Word. We know Him from the Scriptures, for example that He alone is perfectly holy, AllPowerful, All-Knowing, Omnipresent emanating from all goodness, mercy, truth, wisdom, ${ }^{44}$

\section{Living in the devil's intimacy}

1Samuel 28:20. At that very moment Saul fell to the ground because he was very frightened by Samuel's words. Also no more strength, because that day and night he did not eat anything.

It was only because Samuel's words about Israel's future caused Saul to lose faith that he fell to the ground in deep depression and extreme fear. Saul had lost his mind when he was intimidated by the devil's words. Satan or Satan the evil darkness, the evil one, was originally an angel created by God. They are spiritual beings who have freedom and will. The Old and New Testament Scriptures provide many statements about Satan and how he resisted Christ and Christ's reign. The book of Isaiah describes the fall of angels into darkness (Isaiah 14:12-15). Bintang Timur, the son of Fajar in the Indonesian Bible was translated from the Latin "Lucifer". The reason for his downfall was his rebellion and pride.

Satan (used about fifty-two times) comes from the Hebrew word "satan" meaning enemy or adversary (Zech. 3:1; Matt. 4:10; Rev. 12:9; 20:2). Satan (used about thirty-five times) comes from the Greek word "diabolos" which means slanderer (Matt. 4:1; Eph. 4:27; Rev. 12:9;20:2). ${ }^{45}$

The devil often uses some ruse or strategy to hinder God's work in the life of the believer. There are many things that the devil offers to humans, this is what every believer needs to be aware of. Wesley J. Brill explains:

In the beginning the devil was a great and holy angel of light. Satan has rebelled and disobeyed God, but why we do not know. There is little information in the Bible about the cause of sin in the devil, namely pride. Sin comes from the will of the devil. God has made angels with free will, and they will be good if they are led well. So apparently sin began to exist when the devil disobeyed God. ${ }^{46}$

\footnotetext{
${ }^{43}$ Ralph Mahoney, Worship, Shepherd's Staff, New Believer's Training Manual, 7th Edition (India: World Map and Rekka Printers Pvt. Ltd, 2002), 33.

44 John MacArthur, Worship The UltimAte Priority (Chicago: Moody Publisher, 2012), 37.

45 Charles C. Ryrie, Basic Theology, diss., Antoni Stevens, Haryono and Xavier Quentin Pranata, pen., CahyaRabahi (Yogyakarta: Andi Foundation, 1991), I:183.

${ }^{46}$ Wesley J. Brill, Solid Foundation (Bandung: Kalam Hidup Foundation, 1999), 193.
} 
Believers who are intimidated by dark forces in various occult activities are spiritually barren. This kind of person is a person who often lives in sin, because he does not entrust his life to Christ and the Holy Spirit to lead and control him. ${ }^{47}$

As a result of being involved with the first occult practice, the life of church members' fellowship with God is damaged, because being involved with the occult is an abomination to God. Second, his spiritual view of God's truth and grace is less clear because of the grip and power of the devil

of humans who have engaged in occult practices. Third, practically these kind of people are not interested in spiritual things or things that make their spiritual growth such as reading God's Word, praying and praying earnestly. ${ }^{48}$

As a result of the physical, people who want to succeed without having to work hard to involve themselves with occult practices then become prey and victims have to suffer pain because they cannot fulfill the conditions desired by the devil. In this case, the devil works subtly and neatly so that someone who experiences it may not realize or even don't know that the devil has used this gap. ${ }^{49}$

Psychological consequences can be seen from the consequences for the mind, namely the devil's efforts primarily to attack church members is to captivate the minds of believers (Rom. $7: 23 ; 8: 5-7) .28$

The consequences for the will to engage with occult practices are full of arrogance and defiance of the knowledge of God, like to deceive like the devil and full of lies. ${ }^{50}$

Therefore, teaching must be in accordance with God's Word, not with human logic. The Bible plays a very important role in shaping the life of a believer. Against the occult, the Bible clearly teaches the dangers of worshiping occult powers, which concerns the powers of darkness spread by the devil. The role of the Holy Spirit is to give strength and ability in the face of distress, sorrow, fear or in any circumstances. ${ }^{51}$

Personal counseling services. This service can be done by a counselor or a servant of God to help church members free from dark powers. Through this counseling service, the counselor will check the personal acceptance of Jesus; confession to God; ask forgiveness from God; deliverance prayer service; convinced of a new identity in Christ. In addition, daily prayer life can give believers the strength to overcome Satan's offers and is a must for the maturation process

\section{Result Research}

\section{First Hypothesis Testing}

The first hypothesis is proposed: The significant level of the effect of building relationships with others based on I Samuel 28:1-25 on the spiritual quality of the GKE

\footnotetext{
${ }^{47}$ EpafrasMujono, Diktat Lectures: Spiritual Counseling, sem. V, 2006, 19.

${ }^{48}$ Neil T. Anderson, Free from Dark Powers (Yogyakarta: Andi Foundation, 1990), 46

49 Anderson, Who Are You Really (Bandung: Indonesian Baptist Foundation, 1999), 205.

75.

${ }^{50}$ Lin WenasCipto, Fulfilling God's Longing, pen., RezkyStefanus (Jakarta: Bethlehem Publisher, 2002),

51 Marilyn Hickey, Breaking the Shackles of the Curse, pen., EsdinarPurba, pen., Paula Allo (Jakarta: Immanuel Publishing House, 2004), 209
} 
International Journal of Culture and Religious Studies

ISSN 2789-3898 (Online)

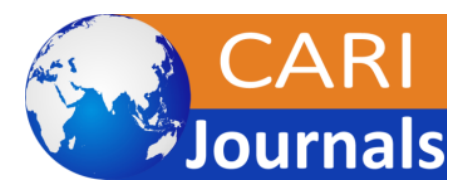

Vol. 2, Issue No. 3, pp 75 - 102, 2021

WWW.carijournals.org

congregation members who attend the TantulakAmbunRutasMatei ceremony in Katingan district, Central Kalimantan is in the quite significant category.

The proof of the first hypothesis is carried out in two stages. The first stage is carried out using several calculations, namely simple correlation analysis $\left(\mathrm{r}_{\mathrm{yd}}\right)$ and the regression significance test (F reg). ${ }^{52}$

\section{Correlations}

\begin{tabular}{|c|c|c|}
\hline & $\begin{array}{l}\text { Building } \\
\text { relationships } \\
\text { with humans }\end{array}$ & $\begin{array}{l}\text { The Spiritual Quality of the } \\
\text { GKE Members of the } \\
\text { Congregation Who } \\
\text { Participated in the } \\
\text { TantulakAmbunRutasMatei } \\
\text { Ceremony in Katingan } \\
\text { Regency, Central } \\
\text { Kalimantan }\end{array}$ \\
\hline $\begin{array}{l}\text { Building relationships Correlation } \\
\text { with humans Sig. (2-tailed) } \\
\text { The Spiritual Quality of Pearson } \\
\text { the GKE Members of Correlation } \\
\text { the Congregation Who Sig. (2-tailed) } \\
\text { Participated in the } \\
\text { TantulakAmbunRutas } \\
\text { Matei Ceremony in N } \\
\text { Katingan Regency, } \\
\text { Central Kalimantan }\end{array}$ & $\begin{array}{l}1 \\
140 \\
.319 * * \\
.000 \\
140\end{array}$ & $\begin{array}{l}.319 * * \\
.000 \\
140 \\
1 \\
\\
140\end{array}$ \\
\hline
\end{tabular}

**. Correlation is significant at the 0.01 level (2-tailed).

Pearson Correlation Strength Table

\begin{tabular}{|l|l|}
\hline Coefficient Interval & Relationship Level \\
\hline $0.800-1,000$ & Very Strong Influence \\
$0.600-0.799$ & Strong Influence \\
$0.400-0.599$ & Influential Enough \\
$\mathbf{0 . 2 0 0}-\mathbf{0 . 3 9 9}$ & Low Influence \\
$0.000-0.199$ & Very Low Influence \\
\hline
\end{tabular}

The magnitude of the correlation coefficient $\left(r_{y 1}\right)$ between the sub-variables Building relationships with humans ( X1 ) on the Spiritual Quality of the GKE Congregational Members Who Participate in the TantulakAmbunRutasMatei Ceremony in Katingan Regency, Central Kalimantan ( Y ) of 0.319 with a positive relationship and influence in the low category. Thus it is known that there is a low/weak effect betweensub variable Building relationships with 
International Journal of Culture and Religious Studies

ISSN 2789-3898 (Online)

Journals

Vol. 2, Issue No. 3, pp 75 - 102, 2021

WWW.carijournals.org

humans ( X1 ) on the Spiritual Quality of the GKE Congregational Members Who Participate in the TantulakAmbunRutasMatei Ceremony in Katingan Regency, Central Kalimantan ( Y ).

Model Summary

\begin{tabular}{|l|l|l|l|l|}
\hline Model & $\mathrm{R}$ & R Square & $\begin{array}{l}\text { Adjusted R } \\
\text { Square }\end{array}$ & $\begin{array}{l}\text { Std. Error of } \\
\text { the Estimate }\end{array}$ \\
\hline 1 & $.319 \mathrm{a}$ & .102 & .095 & 20.91420 \\
\hline
\end{tabular}

a. Predictors: (Constant), Building relationships with humans

The magnitude of the coefficient of determination of variance (r2D1 ) is 0.102 which means thatsubvariablesBuild relationships with humans ( X1)give contribution on the Spiritual Quality of the GKE Congregational Members Who Participate in the TantulakAmbunRutasMatei Ceremony in Katingan Regency, Central Kalimantan (Y) by $10.2 \%$.

ANOVAa

\begin{tabular}{|ll|l|l|l|l|l|}
\hline \multicolumn{2}{|l|}{ Model } & $\begin{array}{l}\text { Sum of } \\
\text { Squares }\end{array}$ & df & $\begin{array}{l}\text { Mean } \\
\text { Square }\end{array}$ & F & Sig. \\
\hline \multirow{2}{*}{1} & Regression & 6843.019 & 1 & 6843.019 & 15,645 & $.000 \mathrm{~b}$ \\
& Residual & 60361,724 & 138 & 437,404 & & \\
& Total & 67204743 & 139 & & & \\
\hline
\end{tabular}

a. Dependent Variable: Spiritual Quality of GKE Congregational Members Who

Participate in the TantulakAmbunRutasMatei Ceremony in Katingan Regency,

Central Kalimantan

b. Predictors: (Constant), Building relationships with humans

\section{Coefficientsa}

\begin{tabular}{|ll|l|l|l|l|l|}
\hline \multicolumn{2}{|l|}{ Model } & \multicolumn{2}{|l|}{$\begin{array}{l}\text { Unstandardized } \\
\text { Coefficients }\end{array}$} & $\begin{array}{l}\text { Standardized } \\
\text { Coefficients }\end{array}$ & $\mathrm{t}$ & Sig. \\
\cline { 2 - 5 } & $\mathrm{B}$ & Std. Error & Beta & & \\
\hline \multirow{2}{*}{1} & $\begin{array}{l}\text { (Constant) } \\
\text { Building relationships } \\
\text { with humans }\end{array}$ & 72,531 & 14,952 & & 4.851 & .000 \\
& .861 & .218 & .319 & 3.955 & .000 \\
\hline
\end{tabular}

a. Dependent Variable: Spiritual Quality of GKE Congregational Members Who Participate in the TantulakAmbunRutasMatei Ceremony in Katingan Regency, Central Kalimantan

Based on the ANOVA table, the significance test with the $t$ test obtained a coefficient of 3.955 with a $\mathrm{P}$ - value of 0.000 which means that it is significant at $<0.01$. So it can be concluded that the hypothesis is accepted because there is a positive and low significant relationship between the sub-variables of Building Relationships with Humans (X1) on the 
International Journal of Culture and Religious Studies

ISSN 2789-3898 (Online)

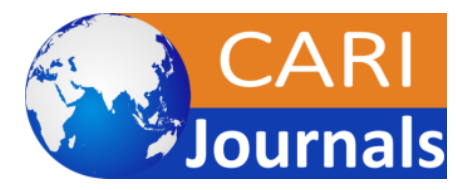

Vol. 2, Issue No. 3, pp 75 - 102, 2021

WWW.carijournals.org

Spiritual Quality of the GKE Congregants Who Participate in the TantulakAmbunRutasMatei Ceremony in Katingan Regency, Central Kalimantan (Y).

To be able to predict the magnitude of the contribution of the sub-variables. Building relationships with humans $\left(\mathrm{X}_{1}\right)$ on the Spiritual Quality of the GKE Congregational Members Who Participate in the TantulakAmbunRutasMatei Ceremony in Katingan Regency, Central Kalimantan (Y) obtained the regression equation $\mathrm{Y}=\mathrm{b}+\mathrm{b} 1 \mathrm{X} 1, \mathrm{Y}=72,531+0.861 \mathrm{X} 1$ with a calculated $\mathrm{F}$ coefficient of 15,645 and a P-value of 0.000 . These results indicate that the regression equation is significant or meaningful so that it can be used to predict the relationship between the increase in variables with the regression equation $\mathrm{Y}=72,531+0.861 \mathrm{X} 1$ which means that if the sub-variable of building relationships with humans (X1) is increased by one unit, the average score of the Spiritual Quality of the Citizens is increased. GKE Congregations Attending the TantulakAmbunRutasMatei Ceremony in Katingan Regency, Central Kalimantan (Y) will increase by 0.861 times from the current condition.

From the two tests above, it can be concluded that the significant level of the influence of building relationships with others based on I Samuel 28:1-25 on the spiritual quality of the GKE congregation who attended the TantulakAmbunRutasMatei ceremony in Katingan district, Central Kalimantan was in the less significant category, thus the hypothesis proposed Significant level of building influence Relationships with others based on I Samuel 28:1-25 on the spiritual quality of the GKE congregation members who attended the TantulakAmbunRutasMatei ceremony in Katingan district, Central Kalimantan, were in the quite significant category and were declared rejected.
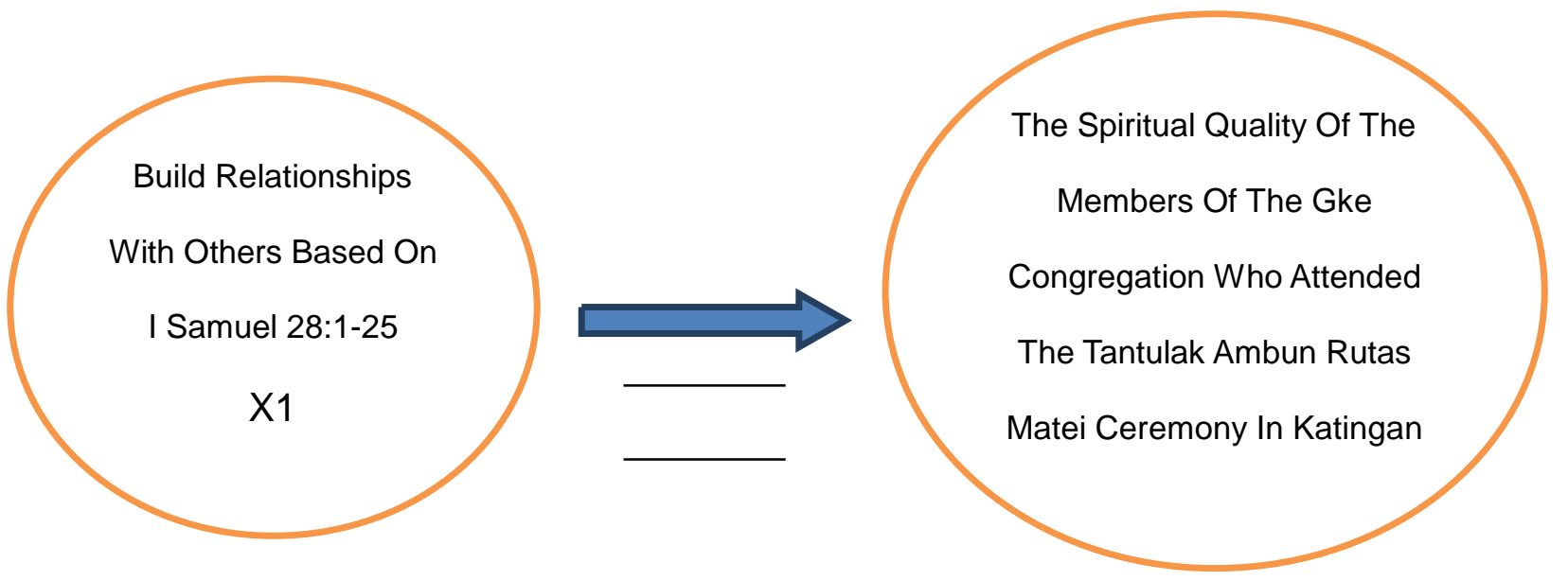

\section{Second Hypothesis Testing}

The first hypothesis is proposed: The significant level of the influence of building a relationship with God based on I Samuel 28:1-25 on the spiritual quality of the GKE congregation who attended the TantulakAmbunRutasMatei ceremony in Katingan district, Central Kalimantan was in the quite significant category. 
The proof of the second hypothesis is carried out in two stages. The first stage is carried out using several calculations, namely simple correlation analysis $\left(r_{y d}\right)$ and the regression significance test (F reg). ${ }^{53}$

\section{Correlations}

\begin{tabular}{|c|c|c|}
\hline & $\begin{array}{l}\text { The Spiritual Quality of the } \\
\text { GKE Members of the } \\
\text { Congregation Who } \\
\text { Participated in the } \\
\text { TantulakAmbunRutasMatei } \\
\text { Ceremony in Katingan } \\
\text { Regency, } \\
\text { Kalimantan }\end{array}$ & $\begin{array}{l}\text { Building a } \\
\text { relationship } \\
\text { with God }\end{array}$ \\
\hline $\begin{array}{l}\text { The Spiritual Quality of Pearson } \\
\text { the GKE Members of Correlation } \\
\text { the Congregation Who Sig. (2-tailed) } \\
\text { Participated in the } \\
\text { TantulakAmbunRutas } \\
\text { Matei Ceremony in } \mathrm{N} \\
\text { Katingan Regency, } \\
\text { Central Kalimantan } \\
\begin{array}{l}\text { Building a relationship Correlation } \\
\text { with God }\end{array}\end{array}$ & $\begin{array}{l}1 \\
140 \\
.441 * * \\
.000 \\
140\end{array}$ & $\begin{array}{l}.441 * * \\
.000 \\
140\end{array}$ \\
\hline
\end{tabular}

**. Correlation is significant at the 0.01 level (2-tailed).

Pearson Correlation Strength Table

\begin{tabular}{|l|l|}
\hline Coefficient Interval & Relationship Level \\
\hline $0.800-1,000$ & Very Strong Influence \\
$0.600-0.799$ & Strong Influence \\
$\mathbf{0 . 4 0 0}-\mathbf{0 . 5 9 9}$ & Influential Enough \\
$0.200-0.399$ & Low Influence \\
$0.000-0.199$ & Very Low Influence \\
\hline
\end{tabular}

The magnitude of the correlation coefficient $\left(r_{\mathrm{y} 1}\right)$ between the sub-variables Building a relationship with God (X2) on the Spiritual Quality of the GKE Members of the Congregation Who Participate in the TantulakAmbunRutasMatei Ceremony in Katingan Regency, Central Kalimantan (Y) of 0.441 with a positive relationship and influence in the category is quite strong. Thus it is known that there is a strong enough influence betweensub-variable Building a 
International Journal of Culture and Religious Studies

ISSN 2789-3898 (Online)

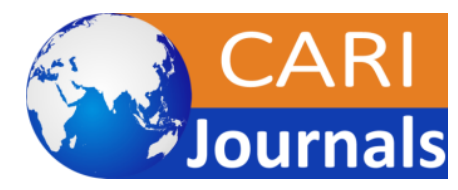

Vol. 2, Issue No. 3, pp 75 - 102, 2021

WWW.carijournals.org

relationship with God (X2) on the Spiritual Quality of the GKE Congregational People Who Participate in the TantulakAmbunRutasMatei Ceremony in Katingan Regency, Central Kalimantan (Y).

Model Summary

\begin{tabular}{|l|l|l|l|l|}
\hline Model & $\mathrm{R}$ & $\mathrm{R}$ Square & $\begin{array}{l}\text { Adjusted R } \\
\text { Square }\end{array}$ & $\begin{array}{l}\text { Std. Error of } \\
\text { the Estimate }\end{array}$ \\
\hline 1 & $.441 \mathrm{a}$ & .194 & .189 & 19.80697 \\
\hline
\end{tabular}

a. Predictors: (Constant), Build a relationship with God

The magnitude of the coefficient of determination of variance (r2D1 ) is 0.194 which means thatsub variable Building a relationship with God ( X2)Contributing to the Spiritual Quality of the GKE Congregational Members Who Participate in the TantulakAmbunRutasMatei Ceremony in Katingan Regency, Central Kalimantan (Y) by $19.4 \%$.

ANOVAa

\begin{tabular}{|ll|l|l|l|l|l|}
\hline \multicolumn{2}{|l|}{ Model } & $\begin{array}{l}\text { Sum } \\
\text { Squares }\end{array}$ & of df & $\begin{array}{l}\text { Mean } \\
\text { Square }\end{array}$ & F & Sig. \\
\hline \multirow{2}{*}{1} & Regression & 13065.137 & 1 & 13065.137 & 33,303 & $.000 \mathrm{~b}$ \\
& Residual & 54139,606 & 138 & 392,316 & & \\
& Total & 67204743 & 139 & & & \\
\hline
\end{tabular}

a. Dependent Variable: Spiritual Quality of GKE Congregational Members Who

Participate in the TantulakAmbunRutasMatei Ceremony in Katingan Regency,

Central Kalimantan

b. Predictors: (Constant), Build a relationship with God

\section{Coefficientsa}

\begin{tabular}{|ll|l|l|l|l|l|}
\hline \multicolumn{2}{|l|}{ Model } & \multicolumn{2}{|l|}{$\begin{array}{l}\text { Unstandardized } \\
\text { Coefficients }\end{array}$} & \multicolumn{2}{l|}{$\begin{array}{l}\text { Standardized } \\
\text { Coefficients }\end{array}$} & Sig. \\
\cline { 2 - 5 } & $\mathrm{B}$ & Std. Error & Beta & & \\
\hline \multirow{2}{*}{1} & $\begin{array}{l}\text { (Constant) } \\
\begin{array}{l}\text { Building a relationship } \\
\text { with God }\end{array}\end{array}$ & 57.610 & 12.871 & & 4.476 & .000 \\
\hline
\end{tabular}

a. Dependent Variable: Spiritual Quality of GKE Congregational Members Who Participate in the TantulakAmbunRutasMatei Ceremony in Katingan Regency, Central Kalimantan

Based on the ANOVA table, the significance test with the test obtained a coefficient of 5.771 with a $\mathrm{P}$ - value of 0.000 which means that it is significant at $<0.01$. So it can be concluded that the hypothesis is accepted because there is a positive and significant relationship between the sub-variables Building a relationship with God (X2) on the Spiritual Quality of the 
International Journal of Culture and Religious Studies

ISSN 2789-3898 (Online)

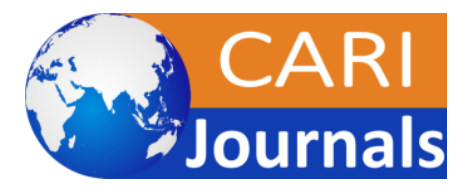

Vol. 2, Issue No. 3, pp 75 - 102, 2021

WWW.carijournals.org

GKE Congregational People Who Participate in the TantulakAmbunRutasMatei Ceremony in Katingan Regency, Central Kalimantan (Y).

To be able to predict the magnitude of the contribution of the sub-variables Building a relationship with God $\left(\mathrm{X}_{2}\right)$ on the Spiritual Quality of the GKE Members of the Congregation Who Participate in the TantulakAmbunRutasMatei Ceremony in Katingan Regency, Central Kalimantan $(\mathrm{Y})$ obtained the regression equation $\mathrm{Y}=\mathrm{b}+\mathrm{b} 2 \mathrm{X} 2, \mathrm{Y}=57.610+1.505 \mathrm{X} 2$ with a calculated $\mathrm{F}$ coefficient of 33,303 and a P-value of 0.000 . These results indicate that the regression equation is significant or meaningful so that it can be used to predict the relationship of increasing variables with the regression equation $\mathrm{Y}=57.610+1.505 \mathrm{X} 2$ which means that if the sub-variable of Building a relationship with God (X2) is increased by one unit, the average score of Quality is increased. The Spirituality of the GKE Congregational Members Who Participate in the TantulakAmbunRutasMatei Ceremony in Katingan Regency, Central Kalimantan (Y) will increase by 1,505 times from the current condition.

From the two tests above, it can be concluded that the significant level of the influence of building a relationship with God based on I Samuel 28:1-25 on the spiritual quality of the GKE congregation members who attended the TantulakAmbunRutasMatei ceremony in Katingan district, Central Kalimantan was in the quite significant category, thus the hypothesis proposed Significant level of building influence The relationship with God based on I Samuel 28:1-25 on the spiritual quality of the members of the GKE congregation who attended the TantulakAmbunRutasMatei ceremony in Katingan district, Central Kalimantan was in the quite significant category and was declared accepted.

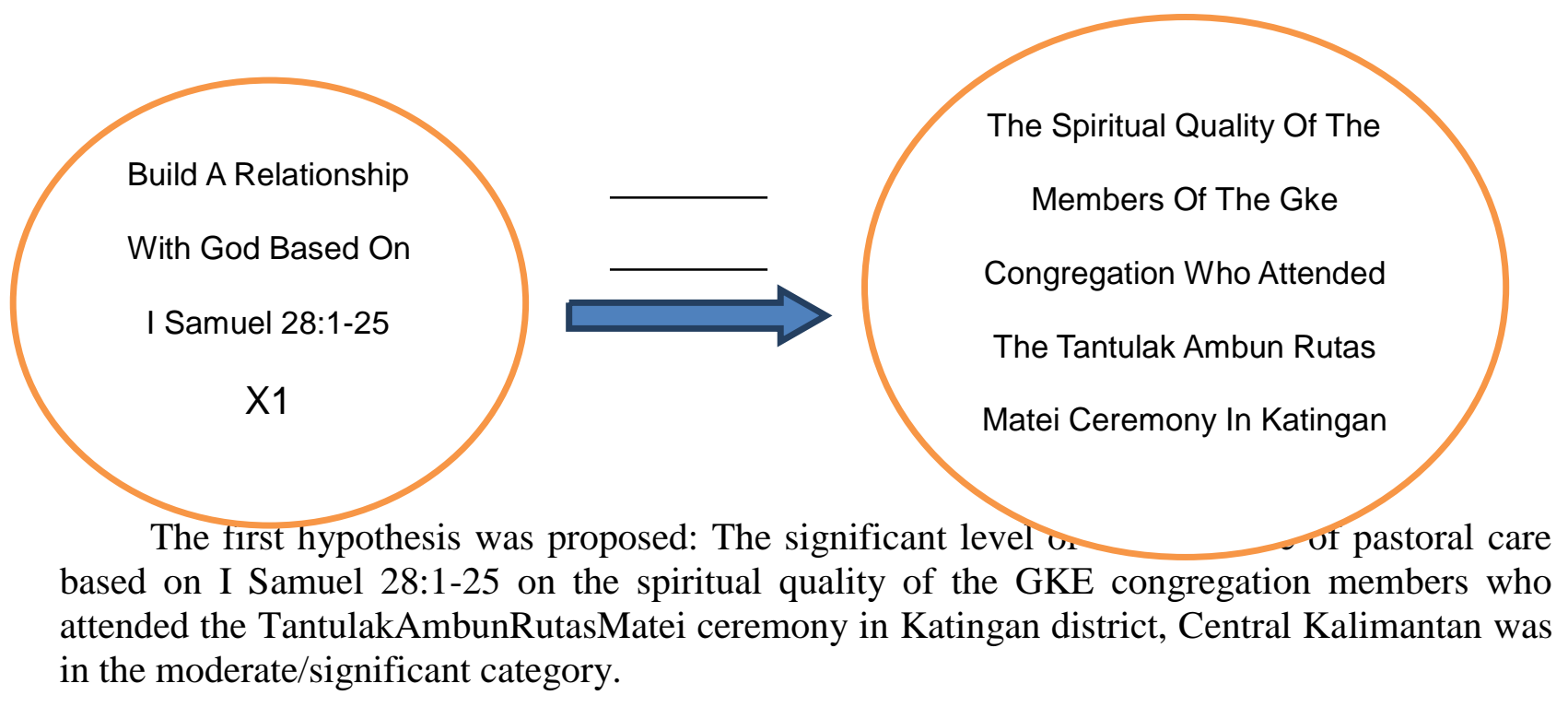

The proof of the third hypothesis is carried out in two stages. The first stage is carried out using several calculations, namely simple correlation analysis $\left(\mathrm{r}_{\mathrm{yd}}\right)$ and the regression significance test (F reg). ${ }^{54}$ 
International Journal of Culture and Religious Studies

ISSN 2789-3898 (Online)

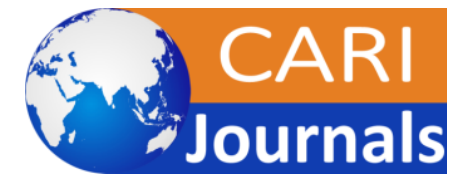

Vol. 2, Issue No. 3, pp 75 - 102, 2021

WWW.carijournals.org

\section{Correlations}

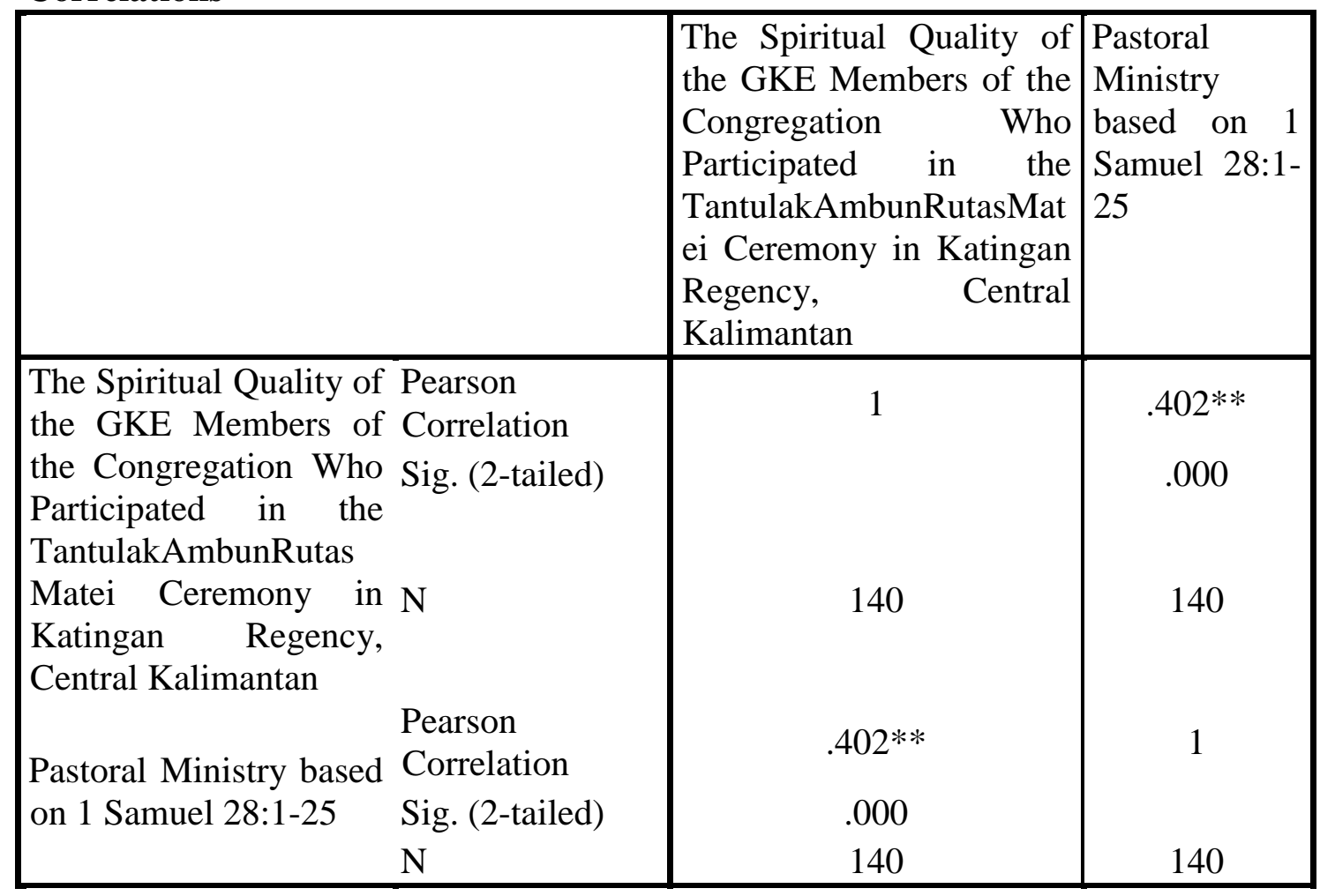

**. Correlation is significant at the 0.01 level (2-tailed).

Pearson Correlation Strength Table

\begin{tabular}{|l|l|}
\hline Coefficient Interval & Relationship Level \\
\hline $0.800-1,000$ & Very Strong Influence \\
$0.600-0.799$ & Strong Influence \\
$\mathbf{0 . 4 0 0}-\mathbf{0 . 5 9 9}$ & Influential Enough \\
$0.200-0.399$ & Low Influence \\
$0.000-0.199$ & Very Low Influence \\
\hline
\end{tabular}

The magnitude of the correlation coefficient ( $\mathrm{r}_{\mathrm{y} 1}$ ) between the variables of pastoral care based on I Samuel 28:1-25 ( X ) on the Spiritual Quality of the GKE Congregational Members Who Participate in the TantulakAmbunRutasMatei Ceremony in Katingan Regency, Central Kalimantan ( $\mathrm{Y}$ ) of 0.402 with a positive relationship and influence in the category is quite strong. Thus it is known that there is a fairly strong influence betweenvariable pastoral care based on I Samuel 28:1-25( X) on the Spiritual Quality of the GKE Congregational People Who Participate in the TantulakAmbunRutasMatei Ceremony in Katingan Regency, Central Kalimantan (Y). 
International Journal of Culture and Religious Studies

ISSN 2789-3898 (Online)

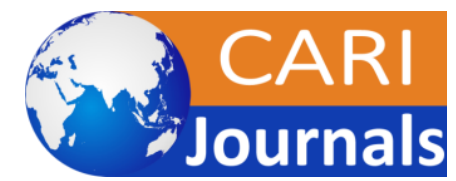

Vol. 2, Issue No. 3, pp 75 - 102, 2021

WWW.carijournals.org

Model Summary
\begin{tabular}{|l|l|l|l|l|}
\hline Model & $\mathrm{R}$ & R Square & $\begin{array}{l}\text { Adjusted R } \\
\text { Square }\end{array}$ & $\begin{array}{l}\text { Std. Error of the } \\
\text { Estimate }\end{array}$ \\
\hline 1 & $.402 \mathrm{a}$ & .162 & .165 & 20.33197 \\
\hline
\end{tabular}

a. Predictors: (Constant), Pastoral Ministry based on 1 Samuel 28:125

The magnitude of the coefficient of determination of variance (r2D1 ) is 0.162 which means thatpastoral care variables based on I Samuel 28:1-25( X)give contribution on the Spiritual Quality of the GKE Congregants Who Participate in the TantulakAmbunRutasMatei Ceremony in Katingan Regency, Central Kalimantan (Y) of $16.2 \%$ and the remaining $83.8 \%$ is influenced by other variables outside of this study.

ANOVAa

\begin{tabular}{|ll|l|l|l|l|l|}
\hline \multicolumn{2}{|l|}{ Model } & $\begin{array}{l}\text { Sum of } \\
\text { Squares }\end{array}$ & df & $\begin{array}{l}\text { Mean } \\
\text { Square }\end{array}$ & F & Sig. \\
\hline \multirow{2}{*}{1} & Regression & 10157.087 & 1 & 10157.087 & 24,570 & $.000 \mathrm{~b}$ \\
& Residual & 57047.656 & 138 & 413,389 & & \\
& Total & 67204743 & 139 & & & \\
\hline
\end{tabular}

a. Dependent Variable: Spiritual Quality of GKE Congregational Members Who Participate in the TantulakAmbunRutasMatei Ceremony in Katingan Regency, Central Kalimantan

b. Predictors: (Constant), Pastoral Ministry based on 1 Samuel 28:1-25

\section{Coefficientsa}

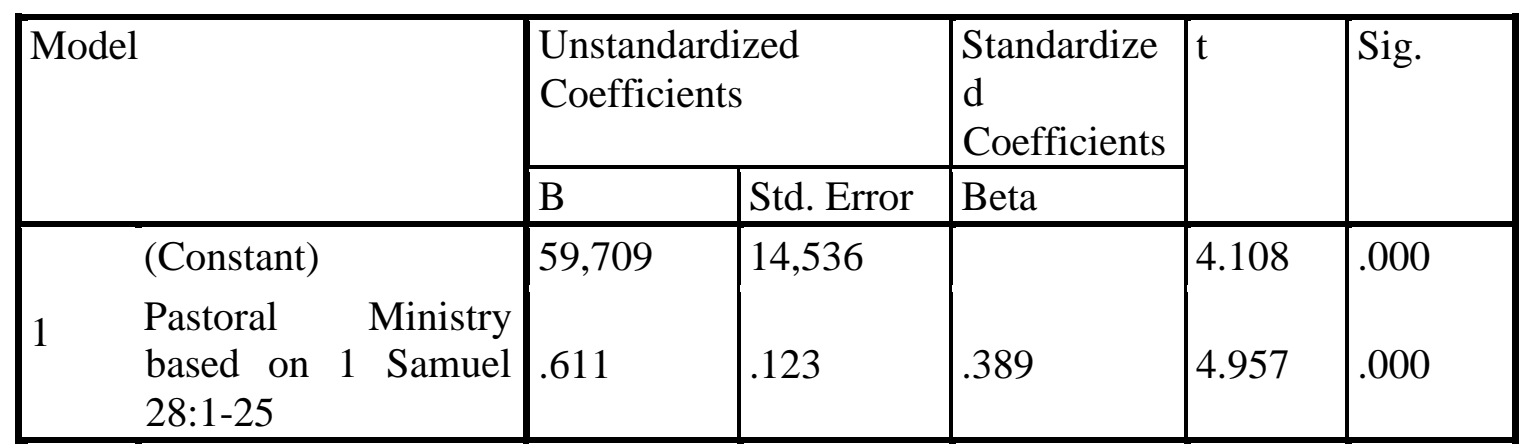

a. Dependent Variable: Spiritual Quality of GKE Congregational Members Who Participate in the TantulakAmbunRutasMatei Ceremony in Katingan Regency, Central Kalimantan

Based on the ANOVA table, the significance test with the t-test obtained a coefficient of 4.957 with a $\mathrm{P}$ - value of 0.000 which means that it is significant at $<0.01$. So it can be concluded that the hypothesis is accepted because there is a positive and significant relationship between pastoral care variables based on I Samuel 28:1-25(X) on the Spiritual Quality of the 
GKE Congregational People Who Participate in the TantulakAmbunRutasMatei Ceremony in Katingan Regency, Central Kalimantan (Y). .

To be able to predict the contribution of pastoral care variables based on I Samuel 28:125(X) to the Spiritual Quality of the GKE Congregational Members Who Participate in the TantulakAmbunRutasMatei Ceremony in Katingan Regency, Central Kalimantan (Y), the regression equation $\mathrm{Y}=\mathrm{b}+\mathrm{bX}, \mathrm{Y}$ is obtained. $=59.709+0.611 \mathrm{X}$ with a calculated $\mathrm{F}$ coefficient of 24,570dan $P$-value of 0.000 . This result shows that the regression equation is significant or meaningful so that it can be used to predict the relationship between the increase in variables with the regression equation $\mathrm{Y}=59.709+0.611 \mathrm{X}$ which means that if the pastoral care variable is based on I Samuel 28:1-25(X) an increase is made. one unit, then the average score of Spiritual Quality of GKE Congregants participating in the TantulakAmbunRutasMatei Ceremony in Katingan Regency, Central Kalimantan (Y) will increase by 0.611 times from the current condition.

From the two tests above, it can be concluded that the significant level of the influence of pastoral care based on I Samuel 28:1-25(X) on the spiritual quality of the GKE congregation who attended the TantulakAmbunRutasMatei ceremony in Katingan district, Central Kalimantan was in the category quite significant, thus the hypothesis proposed Level The significance of pastoral care based on I Samuel 28:1-25(X) on the spiritual quality of the GKE congregation members who attended the TantulakAmbunRutasMatei ceremony in Katingan district, Central Kalimantan was in the category of quite significant, which was declared accepted.
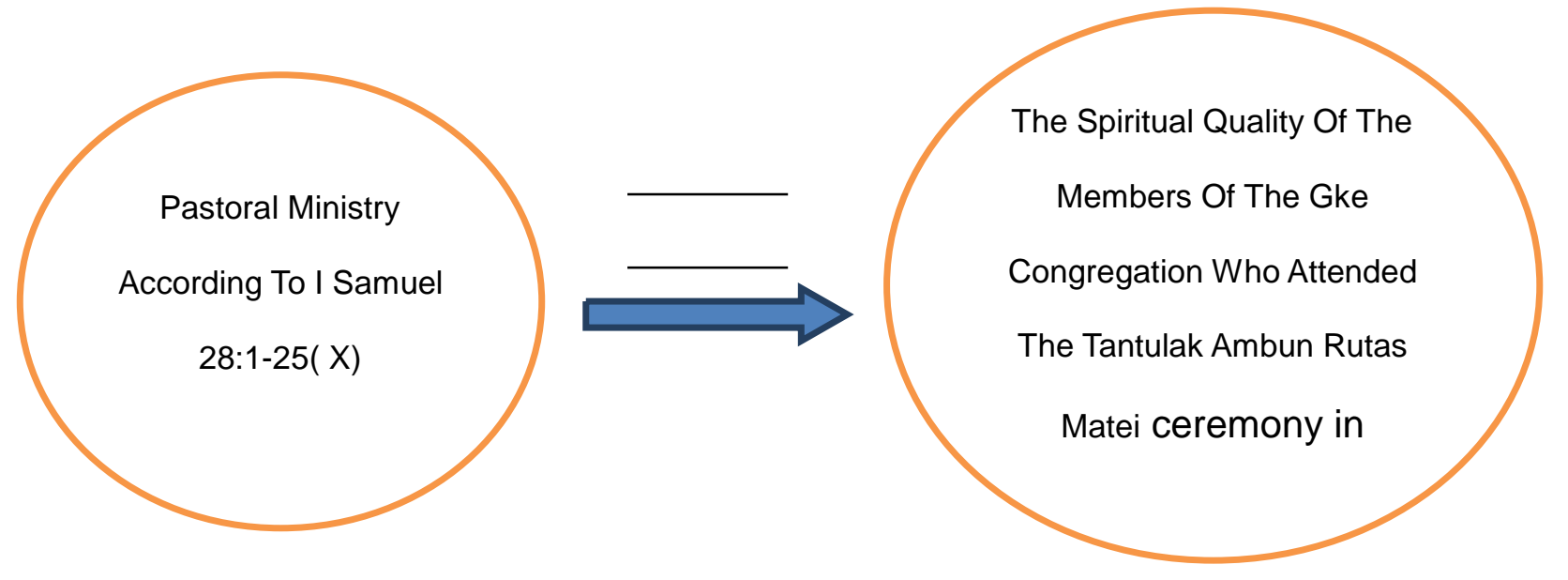
International Journal of Culture and Religious Studies

ISSN 2789-3898 (Online)

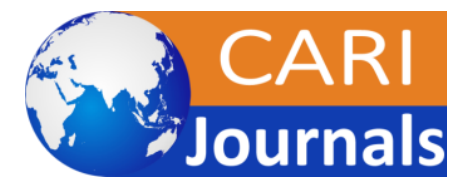

Vol. 2, Issue No. 3, pp 75 - 102, 2021

WWW.carijournals.org

Table of Interpretation of Hypothesis test results

\begin{tabular}{|c|c|c|}
\hline Hypothesis & The proposed hypothesis & Research result \\
\hline 1 & $\begin{array}{l}\text { The significant level of influence of } \\
\text { building relationships with others } \\
\text { based on I Samuel 28:1-25 on the } \\
\text { spiritual quality of the GKE } \\
\text { congregation members who } \\
\text { attended } \\
\text { TantulakAmbunRutasMatei the } \\
\text { ceremony in Katingan district, } \\
\text { Central Kalimantan was in the } \\
\text { quite significant category. }\end{array}$ & $\begin{array}{l}\text { The significant level of influence of } \\
\text { building relationships with others } \\
\text { based on I Samuel } 28: 1-25 \text { on the } \\
\text { spiritual quality of the GKE } \\
\text { congregation members who } \\
\text { attended } \\
\text { TantulakAmbunRutasMatei } \\
\text { ceremony in Katingan district, } \\
\text { Central Kalimantan was in the less } \\
\text { significant category }\end{array}$ \\
\hline 2 & $\begin{array}{l}\text { The significant level of influence of } \\
\text { building a relationship with God } \\
\text { based on I Samuel } 28: 1-25 \text { on the } \\
\text { spiritual quality of the GKE } \\
\text { congregation members who } \\
\text { attended the } \\
\text { TantulakAmbunRutasMatei } \\
\text { ceremony in Katingan district, } \\
\text { Central Kalimantan was in the } \\
\text { moderate or quite significant } \\
\text { category. }\end{array}$ & $\begin{array}{l}\text { The significant level of influence of } \\
\text { building a relationship with God } \\
\text { based on I Samuel } 28: 1-25 \text { on the } \\
\text { spiritual quality of the GKE } \\
\text { congregation members who } \\
\text { attended the } \\
\text { TantulakAmbunRutasMatei } \\
\text { ceremony in Katingan district, } \\
\text { Central Kalimantan was in the } \\
\text { moderate or quite significant } \\
\text { category. }\end{array}$ \\
\hline 3 & $\begin{array}{l}\text { The significant level of the } \\
\text { influence of pastoral care based on } \\
\text { I Samuel 28:1-25 on the spiritual } \\
\text { quality of the GKE congregation } \\
\text { who attended the } \\
\text { TantulakAmbunRutasMatei } \\
\text { ceremony in Katingan district, } \\
\text { Central Kalimantan was in the } \\
\text { moderate / quite significant } \\
\text { category }\end{array}$ & $\begin{array}{l}\text { The significant level of the } \\
\text { influence of pastoral care based on } \\
\text { I Samuel 28:1-25 on the spiritual } \\
\text { quality of the GKE congregation } \\
\text { who attended the } \\
\text { TantulakAmbunRutasMatei } \\
\text { ceremony in Katingan district, } \\
\text { Central Kalimantan was in the } \\
\text { moderate / quite significant } \\
\text { category }\end{array}$ \\
\hline
\end{tabular}

\section{CONCLUSION}

Based on the results of the research presented in the study entitled "The Effect of Pastoral Services Based on I Samuel 28:1-25 on the Spiritual Quality of the GKE Congregational People Who Participate in the TantulakAmbunRutasMatei Ceremony in Katingan Regency, Central Kalimantan". then the following conclusions can be drawn:

First: The results of testing the first hypothesis conclude that the proposed hypothesis, namely the significant level of influence of building relationships with others based on I Samuel 28:1-25 on the spiritual quality of the GKE congregation members who attend the TantulakAmbunRutasMatei ceremony in Katingan district, Central Kalimantan is in the 
International Journal of Culture and Religious Studies

ISSN 2789-3898 (Online)

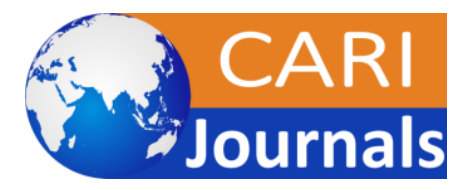

Vol. 2, Issue No. 3, pp 75 - 102, 2021

WWW.carijournals.org

moderate category. significantly rejected. because from the results of statistical calculations through regression and bivariate correlation, it can be seen that the significant level of influence on building relationships with others based on I Samuel 28:of 0.319 with a large contribution between the sub-variables Building relationships with humans (X1) on the Spiritual Quality of the GKE Members of the Congregation Who Participate in the TantulakAmbunRutasMatei Ceremony in Katingan Regency, Central Kalimantan (Y) of 10.2\%. And from the F test, the regression equation $\mathrm{Y}=72,531+0.861 \mathrm{X} 1$ means that if the sub-variable Building relationships with humans (X1) is increased by one unit, the average score for the Spiritual Quality of GKE Congregants Who Participates in the TantulakAmbunRutasMatei Ceremony in Katingan Regency Central Kalimantan ( Y ) will increase by 0.861 times from the current condition.

This also confirms the observations and suspicions of researchers so far that the lack of optimal practice of pastoral services, especially in building relationships with others carried out by GKE, has an impact on the low spiritual quality of the GKE Congregational People Who Participate in the TantulakAmbunRutasMatei Ceremony in Katingan Regency, Central Kalimantan, so that in the future it is necessary to several evaluations were carried out in order to further influence the spiritual quality of the members of the congregation

The second: The results of testing the second hypothesis conclude that the proposed hypothesis, namely the significant level of influence of building a relationship with God based on I Samuel 28:1-25 on the spiritual quality of the GKE congregation who attended the TantulakAmbunRutasMatei ceremony in Katingan district, Central Kalimantan was in the moderate category. significantly accepted. because from the results of statistical calculations through regression and bivariate correlation, it can be seen the magnitude of the correlation coefficient (ry1) between the sub-variables Building a relationship with God (X1) on the Spiritual Quality of the GKE Members of the Congregation Who Participate in the TantulakAmbunRutasMatei Ceremony in Katingan Regency, Central Kalimantan (Y)of 0.441 with a large contribution between the sub-variables Building a relationship with God (X2) on the Spiritual Quality of the GKE Members of the Congregation Who Participate in the TantulakAmbunRutasMatei Ceremony in Katingan Regency, Central Kalimantan (Y) of 19.4\%. And from the $\mathrm{F}$ test, the regression equation $\mathrm{Y}=57.610+1.505 \mathrm{X} 2$ means that if the subvariable Building a relationship with God (X2) is increased by one unit, the average score of the Spiritual Quality of the GKE Congregants Who Participates in the TantulakAmbunRutasMatei Ceremony in Katingan Regency Central Kalimantan ( $\mathrm{Y}$ ) will increase by 1,505 times from the current condition.

This also confirms the observations and suspicions of researchers so far that the practice of pastoral care is still not optimal in building the congregation's relationship with God which is carried out by GKE, so it has an impact on the low spiritual quality of the GKE Congregational People Who Participate in the TantulakAmbunRutasMatei Ceremony in Katingan Regency, Central Kalimantan, so that in the future it is necessary to several evaluations were carried out in order to further influence the spiritual quality of the members of the congregation

Third: The results of testing the third hypothesis conclude that the proposed hypothesis, namely the significant level of influence of pastoral care based on I Samuel 28:1-25 on the spiritual quality of the GKE congregation members who attend the TantulakAmbunRutasMatei ceremony in Katingan district, Central Kalimantan is in the medium category / significant enough to be accepted. because from the results of statistical calculations through regression and 
International Journal of Culture and Religious Studies

ISSN 2789-3898 (Online)

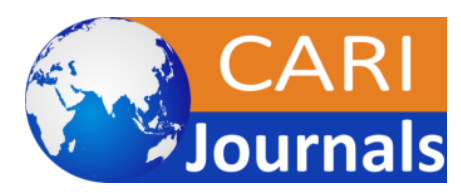

Vol. 2, Issue No. 3, pp 75 - 102, 2021

WWW.carijournals.org

bivariate correlation, it can be seen the magnitude of the correlation coefficient (ry1) between pastoral care variables based on I Samuel 28:1-25 (X) on the Spiritual Quality of the GKE Congregational Members Who Participate in the TantulakAmbunRutasMatei Ceremony in Katingan Regency, Kalimantan Middle ( $\mathrm{Y}$ ) of 0.402 with a large contribution between the variables of pastoral care based on I Samuel 28:1-25 (X) on the Spiritual Quality of the GKE Congregational Members Who Participate in the TantulakAmbunRutasMatei Ceremony in Katingan Regency, Central Kalimantan (Y) of 16.2\%. And from the $\mathrm{F}$ test, the regression equation $\mathrm{Y}=59.709+0.611 \mathrm{X}$ means that if the pastoral service variable based on I Samuel 28:1-25(X) is increased by one unit, the average score of the Spiritual Quality of the GKE Congregational People Who Participates in the TantulakAmbun Ceremony is The Matei Routes in Katingan Regency, Central Kalimantan ( Y ) will increase by 0.611 times from the current condition.

\section{REFERENCES}

Hermogenes Ugang, Tracing the Paths of Nobility, (Jakarta: BPK Gunung Mulia), page 10 Y. Nathan Ilon, Illustration and Embodiment of the Coat of Arms of Batang Garing and Dandang Tingang: A

The Conception of Humanizing Humanity in the Philosophy of the Ngaju Dayak Tribe, Central Kalimantan,

(Palangka Raya: PBP DATI I Central Kalimantan, 1991), 7

Hermogenes Ugang,Op - Cit, 11 - 12

Hans Scharer, Op-Cit, pp. 124-125

Geoffrey. W. Bromiley. The International Standard Bible Encyclopedia, Volume Four: QZ. 1988. Michigan: Grand Rapids, 472.

Theodore J. Lewis. Cults of the Dead in Ancient Israel and Ugarit in Journal of Near Eastern Studies, Vol. 53, No. 2 (Apr., 1994), 153.

Mark S. Smith and Elizabeth M. Bloch-Smith. Death and Afterlife in Ugarit and Israel, in Journal of the American Oriental Society, Vol. 108, No. 2 (Apr. - Jun., 1988), 281.

Mark S. Smith and Elizabeth M. Bloch-Smith. Death and Afterlife in Ugarit and Israel, 281

Henry Preserved Smith. A Critical and Exegetical Commentary on The Books of Samuel. 1977. Edinburgh: T\&T Clark, 239.

In the belief system of the Ngaju Dayak people, hadat/adat is the rule of life that was revealed directly by RanyingHatalaLangit.

Hermogenes Ugang, Tracing the Paths of Nobility, (Jakarta: BPK GunungMulia, 1983), p. 50.

YakobTomatala, Mission Theology., YT Leadership Foundation, Jakarta, 2003, page 61

Walter Brueggemann. First and Second Samuel Interpretation: A Bible Commentary for Teaching and Preaching. 1990. USA: John Knox Press, 192.

Walter Brueggemann. First and Second Samuel Interpretation: A Bible Commentary for Teaching and Preaching, 193.

JD Engel, Pastoral and Basic Needs Counseling, (Jakarta:BPKGunungMulia, 2016), page 5

Mark S. Smith and Elizabeth M. Bloch-Smith. Death and Afterlife in Ugarit and Israel, 281 Henry Preserved Smith. A Critical and Exegetical Commentary on The Books of Samuel. 1977. Edinburgh: T\&T Clark, 239. 
International Journal of Culture and Religious Studies

ISSN 2789-3898 (Online)

Vol. 2, Issue No. 3, pp 75 - 102, 2021

WWW.carijournals.org

Handbook of Today's Religions: Understanding the Occult (San Bernardino: Here's Life: 1982),

p.164

Ocean, World of the Dead, (Bandung: Revival, 1996). p, 48

Andereas Samudera, Barang Tumpas, (Bandung:: Revival, 1998), p. 21

Abineno. JL Ch. Humans and Others in the World, (Jakarta; Gunung Mulia), 1990, p. 24

David N Freedman, (Ed), Eerdmans Dictionary of The Bible, Michigan:Word Eerdmarts

Pblingshing Company, 2000, sv "mut and thanatos"

Donald Guthrie, New Testament Theology 1: God, Man, Christ, (Jakarta: BPK Gunung Mulia, 1991), pp. 44-45

Harun Hadiwijono. Christian Faith, (Jakarta: BPK Gunung Mulia. 2003), pp. 77-78

Yohanes Calvin, Institute: Teaching Christianity (Jakarta: BPK Gunung Mulia, 1985), p. 21

RCSproul, Fundamental Truths of the Christian Faith, Trans. R.Tanudjaja, (Malang: Department of Literature SAAT, 1998), p. 88

Andreas Kabanga', Completely Dead Man: A Study of Christian Anthropology, Introduction:

Prof.(Em) Dr. Solarso Sopater, Yogyakarta: Media Pressindo, 2002, pp. 76-77

Djohan E. Handoyo, Praise And Worship (Yogyakarta: ANDI Publisher, 2007), 50.

John MacArthur, Top Priorities in Worship (Bandung: Kalam Hidup, 2001), 151

Chris Jack, "Understanding Worship: Part 2" in Worshiping in Spirit and Truth, sixth edition (Yogyakarta: ANDI Publisher, 2010), 80.

Matt Redman, Worshiping in Spirit and Truth, sixth printing (Yogyakarta: ANDI Publishers, 2010), 83.

John MacArthur, JR, MAIN PRIORITIES IN WORSHIP (Bandung: Kalam Hidup, 2011), 26.

Marvin E. Tate, HolmAn Bible DictionAry for Window version 1.0g(Parsons Technology, 1994), sv "worship"

Jey J. Kanaragaraj, "Worship, Sacrifice and Mission: Themes Interlocked in John," Indian Journal of Theology 40.1\&2 (1998):17.

Ralph Mahoney, Worship, Shepherd's Staff, New Believer's Training Manual, 7th Edition (India: World Map and Rekka Printers Pvt. Ltd, 2002), 33.

John MacArthur, Worship TheUltimAte Priority (Chicago: Moody Publisher, 2012),

37.

Charles C. Ryrie, Basic Theology, diss., Antoni Stevens, Haryono and Xavier Quentin Pranata, pen., CahyaRabahi (Yogyakarta: Andi Foundation, 1991), I:183.

Wesley J. Brill, Solid Foundation (Bandung: Kalam Hidup Foundation, 1999), 193.

EpafrasMujono, Diktat Lectures: Spiritual Counseling, sem. V, 2006, 19.

Neil T. Anderson, Free from Dark Powers (Yogyakarta: Andi Foundation, 1990), 46

Anderson, Who Are You Really (Bandung: Indonesian Baptist Foundation, 1999), 205.

Lin WenasCipto, Fulfilling God's Longing, pen., RezkyStefanus (Jakarta: Bethlehem Publisher, 2002), 75.

Marilyn Hickey, Breaking the Shackles of the Curse, pen., EsdinarPurba, pen., Paula Allo (Jakarta: Immanuel Publishing House, 2004), 209

Dwi Priyatno, Understand statistical analysis of data with SPSS, 312 